Article

\title{
Thermal Behavior of Ceramic Bodies Based on Estonian Clay from the Arumetsa Deposit with Oil Shale Ash and Clinker Dust Additives
}

\author{
Tiit Kaljuvee $^{1, *}$, Igor Štubňa ${ }^{2}$, Tomáš Húlan ${ }^{2}{ }^{\mathbb{D}}$, Mai Uibu ${ }^{1}$, Marve Einard ${ }^{1}$, Rainer Traksmaa ${ }^{1}$, Mart Viljus $^{1}$, \\ Jekaterina Jefimova ${ }^{3}$ and Andres Trikkel ${ }^{1}$ D
}

1 Laboratory of Inorganic Materials, Tallinn University of Technology, Ehitajate Tee 5, 19086 Tallinn, Estonia; mai.uibu@taltech.ee (M.U.); marve.einard@taltech.ee (M.E.); rainer.traksmaa@taltech.ee (R.T.); mart.viljus@taltech.ee (M.V.); andres.trikkel@taltech.ee (A.T.)

2 Department of Physics, Constantine the Philosopher University, A. Hlinku 1, 94901 Nitra, Slovakia; istubna@ukf.sk (I.Š.); thulan@ukf.sk (T.H.)

3 Estonian Marine Institute, University of Tartu, Mäealuse Tee 14, 12618 Tallinn, Estonia; jekaterina.jefimova@ut.ee

* Correspondence: tiit.kaljuvee@taltech.ee

\section{check for}

updates

Citation: Kaljuvee, T.; Štubňa, I.;

Húlan, T.; Uibu, M.; Einard, M.;

Traksmaa, R.; Viljus, M.; Jefimova, J.;

Trikkel, A. Thermal Behavior of

Ceramic Bodies Based on Estonian

Clay from the Arumetsa Deposit with

Oil Shale Ash and Clinker Dust

Additives. Processes 2022, 10, 46.

https://doi.org/10.3390/pr10010046

Academic Editors: Sung-Churl Choi and Gye Seok An

Received: 25 November 2021

Accepted: 21 December 2021

Published: 27 December 2021

Publisher's Note: MDPI stays neutral with regard to jurisdictional claims in published maps and institutional affiliations.

Copyright: (C) 2021 by the authors Licensee MDPI, Basel, Switzerland. This article is an open access article distributed under the terms and conditions of the Creative Commons Attribution (CC BY) license (https:// creativecommons.org/licenses/by/ $4.0 /)$.

\begin{abstract}
The thermal behavior of green clay samples from the Arumetsa and Füzérradvány deposits (Hungary) and the influence of two new types of Estonian oil shale (OS) ashes and cement bypass dust (clinker dust) additives on it were the objectives of this study. Thermal and thermo-dilatometric analysis methods were applied using a Setaram Setsys 1750 thermoanalyzer coupled with a Pfeiffer Omnistar spectrometer and a Setaram Setsys 1750 CS Evolution dilatometer. The kinetic parameters were calculated based on the differential isoconversional method of Friedman. The results of the thermal analysis of clays and blends indicated the emission of physically bound water at $200-250{ }^{\circ} \mathrm{C}$. At temperatures from $200-250{ }^{\circ} \mathrm{C}$ to $550-600{ }^{\circ} \mathrm{C}$ the release of water is caused by oxidation of organic matter and dehydroxylation of different clay minerals like illite, illite-smectite, mica and kaolin. From blends, in addition, also from the decomposition of portlandite. The emission of $\mathrm{CO}_{2}$ at these temperatures was a result of the oxidation of organic matter contained in the clays. In the temperature range from $550-600{ }^{\circ} \mathrm{C}$ to $800-900^{\circ} \mathrm{C}$, the mass loss was caused by ongoing dehydroxylation processes in clay minerals but was mainly due to the decomposition of the carbonates contained in the OS ashes and clinker dust. These processes were accompanied by contraction and expansion of the ceramic bodies with the corresponding changes in the SSA and porosity values of the samples. Therefore, the decomposition of the clays took place in one step which blends in two steps. At first, dehydroxylation of the clay minerals occurs, followed by decomposition of the carbonates. The value of the conversion-dependent activation energy $E$ along the reaction progress $\alpha$ varied for the Arumetsa and illitic clay between 75-182 and 9-206 $\mathrm{kJ} \mathrm{mol}^{-1}$, respectively. For the blends based on Arumetsa and illitic clay, the activation energy of the first step varied between 14-193 and 5-205 kJ mol ${ }^{-1}$, and for the second step, it was between 15-390 and 135-235 $\mathrm{kJ} \mathrm{mol}^{-1}$, respectively, indicating the complex mechanism of the processes.
\end{abstract}

Keywords: ceramics; clay; clinker dust; FTIR; kinetics; oil shale ash; TG-DTA-MS; TMA

\section{Introduction}

Previously, the influence of new types of OS ashes and clinker dust on the thermal behavior of Estonian clay from Kunda deposits has been studied [1]. In this research, the results of studying the influence of these ashes and clinker dust additives on the thermal behavior of Estonian clay from another big deposit (i.e., the Arumetsa deposit) is presented. The ashes used were formed through the circulated fluidized bed combustion of OS at the Auvere Power Plant (CFBC at temperatures $750-830^{\circ} \mathrm{C}$; fly ash (FA)) and through 
pulverized firing of it at the Eesti Power Plant (PF, $1200-1400{ }^{\circ} \mathrm{C}$; DeSOx ash). Clinker dust was collected from the Kunda Nordic Cement Factory. The total amount of OS ashes and clinker dust is decreasing, according to the reduction of OS-based electricity production in Estonia and improvements in the exploited technologies for OS combustion and cement production [2,3]. Nevertheless, the amount of OS ashes formed in 2020 was on the level of 2.6 million tons, and the clinker dust in 2018 totaled 30,000 tons. Most of these wastes were deposited in dumps.

Considering the increasing demand of circular economies [4,5], it will be of the highest importance to find possibilities for reusing these wastes. One possibility could be reuse of these wastes in the ceramic industry by replacing a part of the clay (or grog) with OS ashes or clinker dust additives.

The influence of ashes with different origins like coal, biomass or MSW incineration ashes on the thermal behavior and physical, chemical and mechanical properties of different ceramic goods has been widely studied [6-19].

Porous cordierite ceramics produced from stevensite-rich clay and an andalusite mixture with an oil shale additive as a natural pore-forming agent were studied in [6]. It was established that the microstructure and mechanical properties were strongly influenced by the sintering conditions and the amount of oil shale added (0-20 wt.\%). The maximum addition of oil shale resulted in an increase in the pore size and open porosity from $17.7 \%$ to $52.8 \%$. The gradual increase in the oil shale addition revealed a strong decline in mechanical properties such as flexural strength, tensile strength and Young's modulus.

In [7], the compositions were based on different amounts of clay and recycled ceramics, and wastepaper pulp was used as a pore-forming agent in different proportions in order to increase and control the total porosity of the final bricks. The small pores with diameters less than $0.1 \mathrm{~mm}$ affected the thermal conductivity and the compressive strength less than the macro-pores with diameters higher than $0.1 \mathrm{~mm}$. The thermal conductivity decreased from 0.75 to $0.58 \mathrm{Wm}^{-1} \mathrm{~K}^{-1}$ by increasing the porosity from $3.5 \%$ to $35 \%$.

Ceramics based on incinerated paper mill sludge and glass cullet from energy saving lamps blended with different amounts (10-40\%) of red clay, yellow clay and high-grade kaolin were studied in [8]. It was established that compositions containing 30-40\% red or yellow clay or $20-40 \%$ kaolin displayed shrinkage values below $10 \%$ at the temperature interval from 1040 to $1140{ }^{\circ} \mathrm{C}$. The crystal structure of the fired materials is mainly caused by nature, the chemical compositions and crystal phases of the recycled materials and only minimally by the characteristics of the natural clays.

Mixtures containing brick raw materials and the paper waste were also studied in [9]. The compressive strength of fired bricks with $10 \mathrm{wt}$.\% paper wastes were higher than $20 \mathrm{MPa}$, while the bulk density of the bricks decreased from 1.85 to $1.62 \mathrm{~g} \mathrm{~cm}^{-3}$, and the thermal conductivity decreased from 0.83 to $0.59 \mathrm{~W} \mathrm{~m} \mathrm{~m}^{-1} \mathrm{~K}^{-1}$, but the porosity of the samples without and with additives increased from 30.8 to $38.9 \%$, respectively.

In [10], bricks based on clay bodies with rice husk additives up to $10 \%$ satisfied the requirements for building materials for indoor structural applications.

As an additive, sugarcane bagasse ash up to $10 \%$ content in the production of clay bricks was successfully tested in [11] without decreasing the mechanical strength of the final product, indicating the possible reuse of this waste in ceramics.

Sugarcane bagasse ash as well as flat glass waste were also studied as possible additives in replacing a part of natural raw materials (kaolinic clay and quartz) in the production of wall tile pastes [12]. It was established that sugarcane bagasse ash and flat glass waste influenced the thermal behavior of the paste differently. Replacing a part of the quartz with sugarcane bagasse ash in amounts up to $5 \%$ tended to increase the mass loss, resulting in wall tiles with a higher open porosity. On the contrary, partial replacement of kaolinic clay with flat glass waste resulted in a denser microstructure.

Replacement of clay up to $20 \mathrm{wt}$.\% with wood waste incinerator ash [13] or with olive pomace bottom ash [14] was followed by a decrease in the bulk density and an increase in the porosity of the bricks. The compressive strength of the bricks decreased but did 
not fall below the limits for the standards of conventional bricks. Adding the biomass gasification fly ash of to $20 \mathrm{wt}$.\% in the clay mixtures also enabled obtaining clay bodies which corresponded to the requirements for facing bricks [15].

Two types of bricks produced in the SanMarco-Terreal factory in Italy were compared with the newly designed bricks obtained from the same clay with the addition of ceramic sludge instead of the traditionally used siliceous sand [16]. The results indicated that the bricks produced with added ceramic sludge could substitute traditional bricks well, maintaining their mechanical properties. The only drawback was that these new materials did not satisfy the freeze-thaw cycle requirements, decreasing their usability in cold climate conditions.

Coal fly ash (5\%) was used as an additive for preparing bricks based on clays from the Guadix and Viznar deposits in Spain. The texture of the bricks with and without fly ash were very similar, except that the samples with the additive contained spherical fly ash particles with diameters ranging between 0.1 and $10 \mu \mathrm{m}$, leading to a reduction in the density of the bricks [17].

The effect of coal fly ash with a high clay replacement ratio $(60 \%$ or $80 \%)$ on the firing parameters and properties of bricks were studied by Lingling et al. [18]. The sintering temperature increased from $1050{ }^{\circ} \mathrm{C}$ to $1100-1150{ }^{\circ} \mathrm{C}$, followed by an increase in compressive strength, low water absorption and high resistance to frost-melting cycles.

The optimum amount of fluidized bed fly ash in a composition with kaolinic clay for the production of dry pressed ceramic tiles was on the level of 20\%, as shown in [19]. Fluidized bed fly ash reduces firing shrinkage and increases the porosity of the body, being more remarkable when non-milled ash was used.

Therefore, different types of wastes and additives have been studied to find possibilities for reusing them in the ceramic industry. The aim of this research was to study the influence of new types of oil shale ashes and clinker dust from electricity and cement production on the thermal behavior and physical and chemical characteristics of ceramic bodies based on Estonian clay from the Arumetsa deposit.

\section{Materials and Methods}

The mineralogical and chemical compositions of the clays, OS ashes and clinker dust studied are presented in Tables 1 and 2. The ashes used as additives were formed via circulated fluidized bed combustion (CFBC) of Estonian OS at the Auvere Power Plant (at 750-830 ${ }^{\circ} \mathrm{C}$ with electrostatic precipitator ash or fly ash; Auvere FA) and by pulverized firing of it at the Eesti Power Plant (at $1200-1400{ }^{\circ} \mathrm{C}$, DeSOx ash; DeSOx). Clinker dust (CD) was formed from the manufacturing of cement at the Kunda Nordic Cement Factory (Kunda NCF).

The content of illite, illite-smectite and mica was high in both of the studied clays (48.9\% in the Arumetsa clay and $76.4 \%$ in the illitic clay). Both clays also contained quartz (18.5\% and $17.5 \%$, respectively) and orthoclase (3.8\% and $5.8 \%$, respectively). In addition, the Arumetsa clay contained some amount of other clay minerals like kaolin, amphipole and chlorite, as well as plagioclase, hematite and calcite-dolomite (Table 1).

The contents of calcite, lime and anhydrite in Auvere FA were 9.8\%, 8.7\% and 6.0\%, respectively, and in DeSOx, they were $8.8 \%, 6.9 \%$ and $10.7 \%$, respectively. The content of calcite in the clinker dust was on the level of $47.3 \%$, while that of arcanite was $15.9 \%$. The content of portlandite in the ashes was high (10.5\% in DeSOx and $7.0 \%$ in Auvere FA). The ashes and clinker dust also contained quartz and different silicates, having primary ones like orthoclase as well as secondary ones like belite and merwinite. All additives contained some amount of periclase, and the ashes were also characterized by high contents of amorphous phase (20.0\% in Auvere FA and 24.6\% in DeSOx (Table 1)).

The content of organic carbon in the Arumetsa and illitic clays was 0.32 and $0.06 \%$, while the BET specific surface area (SSA) was 44.71 and $48.79 \mathrm{~m}^{2} \mathrm{~g}^{-1}$ and the porosity was 77.63 and $82.14 \mathrm{~mm}^{3} \mathrm{~g}^{-1}$, respectively (Table 2). 
Table 1. Mineralogical compositions (\%) of initial samples.

\begin{tabular}{|c|c|c|c|c|c|}
\hline $\begin{array}{l}\text { Compound or } \\
\text { Formula }\end{array}$ & $\begin{array}{l}\text { Arumetsa } \\
\text { Clay }\end{array}$ & Illitic Clay & $\begin{array}{c}\text { PF/ } \\
\text { DeSOx }\end{array}$ & $\begin{array}{c}\text { CFBC/ } \\
\text { Auvere FA }\end{array}$ & $\begin{array}{c}\text { Kunda NCF/ } \\
\text { CD }\end{array}$ \\
\hline Amorphous phase & - & - & 24.6 & 20.0 & - \\
\hline Kaolin, $\mathrm{Al}_{2} \mathrm{Si}_{2} \mathrm{O}_{5}(\mathrm{OH})_{4}$ & 11.6 & - & - & - & - \\
\hline $\begin{array}{l}\text { Illite, illite-smectite, mica, } \\
\mathrm{KAl}_{2}\left(\mathrm{AlSi}_{3} \mathrm{O}_{10}\right)(\mathrm{OH})_{2}\end{array}$ & 48.9 & 76.4 & - & - & 7.2 \\
\hline $\begin{array}{c}\text { Amphipole, } \\
\mathrm{NaCa}_{2}\left(\mathrm{Fe}^{2+,} \mathrm{Fe}^{3+}\right) \mathrm{Si}_{6} \mathrm{Al}_{2} \mathrm{O}_{22}(\mathrm{OH})_{2}\end{array}$ & 1.6 & - & - & - & - \\
\hline Lime, $\mathrm{CaO}$ & - & - & 6.9 & 8.7 & 0.9 \\
\hline Calcite, $\mathrm{CaCO}_{3}$ & 0.6 & - & 8.8 & 9.8 & 47.3 \\
\hline Dolomite, $\mathrm{CaMg}\left(\mathrm{CO}_{3) 2}\right.$ & 2.1 & - & - & - & - \\
\hline Anhydrite, $\mathrm{CaSO}_{4}$ & - & - & 10.7 & 6.0 & 0.4 \\
\hline Quartz, $\mathrm{SiO}_{2}$ & 18.5 & 17.5 & 7.8 & 10.7 & 11.4 \\
\hline Orthoclase, $\mathrm{KAlSi}_{3} \mathrm{O}_{8}$ & 3.8 & 5.8 & 5.8 & 13.5 & 1.8 \\
\hline Plagioclase, $\mathrm{NaCaAlSi}_{3} \mathrm{O}_{6}$ & 5.3 & - & - & - & - \\
\hline Belite, $\mathrm{Ca}_{2} \mathrm{SiO}_{4}$ & - & - & 12.1 & 12.4 & 8.5 \\
\hline Merwinite, $\mathrm{Ca}_{3} \mathrm{Mg}\left(\mathrm{SiO}_{4}\right)_{2}$ & - & - & 4.4 & 1.8 & 3.0 \\
\hline Hematite, $\mathrm{Fe}_{2} \mathrm{O}_{3}$ & 1.2 & - & 1.3 & 3.6 & - \\
\hline Periclase, $\mathrm{MgO}$ & - & - & 3.5 & 1.6 & 0.6 \\
\hline Arcanite, $\mathrm{K}_{2} \mathrm{SO}_{4}$ & - & - & 0.4 & 1.0 & 15.9 \\
\hline Portlandite, $\mathrm{Ca}(\mathrm{OH})_{2}$ & - & - & 10.5 & 7.0 & - \\
\hline $\begin{array}{c}\text { Chlorite, } \\
(\mathrm{Mg}, \mathrm{Al}, \mathrm{Fe})_{6}(\mathrm{SiAl})_{4} \mathrm{O}_{10}(\mathrm{OH})_{2}\end{array}$ & 4.9 & - & - & - & - \\
\hline
\end{tabular}

Table 2. Chemical composition (\%) and some physicochemical characteristics of initial samples.

\begin{tabular}{|c|c|c|c|c|c|}
\hline \multirow[b]{2}{*}{ Item } & \multicolumn{5}{|c|}{ Sample or Content (\%) } \\
\hline & $\begin{array}{c}\text { Arumetsa } \\
\text { Clay }\end{array}$ & Illitic Clay & $\begin{array}{c}\text { PF, } \\
\text { DeSOx }\end{array}$ & $\begin{array}{c}\text { CFBC, } \\
\text { Auvere FA }\end{array}$ & $\begin{array}{c}\text { Kunda NCF, } \\
\text { CD }\end{array}$ \\
\hline $\mathrm{CaO}^{\text {total }}$ & 1.5 & 0.3 & 36.3 & 36.9 & 41.0 \\
\hline $\mathrm{CaO}^{\text {free }}$ & - & - & 7.9 & 11.8 & 3.8 \\
\hline $\mathrm{MgO}$ & 2.7 & 1.2 & 4.7 & 2.5 & 6.5 \\
\hline $\mathrm{C}_{\mathrm{TC}} / \mathrm{C}_{\mathrm{TIC}}$ & $0.39 / 0.07$ & $0.06 /$ & $1.01 / 1.01$ & $1.47 / 1.39$ & $5.6 / 5.6$ \\
\hline$C^{\text {org } *}$ & 0.32 & 0.06 & - & 0.08 & - \\
\hline $\mathrm{SiO}_{2}$ & 56.5 & 57.0 & 28.5 & 24.2 & 14.6 \\
\hline $\mathrm{Al}_{2} \mathrm{O}_{3}$ & 18.4 & 25.0 & 7.3 & 11.2 & 3.5 \\
\hline $\mathrm{Fe}_{2} \mathrm{O}_{3}$ & 6.8 & 1.9 & 3.6 & 5.6 & 1.2 \\
\hline $\mathrm{SO}_{3}$ total & 0.08 & 0.08 & 9.3 & 3.5 & 7.2 \\
\hline $\mathrm{K}_{2} \mathrm{O}$ & 4.5 & 8.5 & 3.6 & 3.8 & 8.2 \\
\hline $\mathrm{Na}_{2} \mathrm{O}$ & 0.58 & 0.02 & 0.32 & 0.10 & - \\
\hline LOI $950{ }^{\circ} \mathrm{C}$ & 6.9 & 7.0 & 6.7 & 9.6 & 24.2 \\
\hline $\begin{array}{l}\text { BET SSA } \\
\left(\mathrm{m}^{2} \mathrm{~g}^{-1}\right)\end{array}$ & 44.71 & 48.79 & 1.43 & 4.68 & 3.00 \\
\hline Porosity $\left(\mathrm{mm}^{3} \mathrm{~g}^{-1}\right)$ & 77.63 & 82.14 & 3.84 & 8.87 & 5.15 \\
\hline $\mathrm{d}^{\text {mean }}(\mu \mathrm{m})$ & 12.7 & 17.3 & 49.6 & 21.9 & 41.1 \\
\hline
\end{tabular}

${ }^{*} \mathrm{C}^{\text {org }}=\mathrm{C}^{\mathrm{TC}}-\mathrm{C}^{\mathrm{TIC}} ; \mathrm{TC}=$ total carbon, TIC = total inorganic carbon.

The content of sulfur calculated as $\mathrm{SO}_{3}$ in the Auvere $\mathrm{FA}$ was 3.5\%, while it was 9.3\% in the DeSOx $9.3 \%$ and $7.2 \%$ in the clinker dust. The content of free $\mathrm{CaO}$ in the Auvere 
FA and DeSOx was 11.8 and $7.9 \%$, respectively, and in the clinker dust, it was only $3.8 \%$ (Table 2).

The value of the SSA for the Auvere FA and DeSOx was 4.68 and $1.4 \mathrm{~m}^{2} \mathrm{~g}^{-1}$, and the porosity was 8.87 and $3.84 \mathrm{~mm}^{3} \mathrm{~g}^{-1}$, respectively, while for the clinker dust, these values were $3.00 \mathrm{~m}^{2} \mathrm{~g}^{-1}$ and $5.15 \mathrm{~mm}^{3} \mathrm{~g}^{-1}$. The mean particle size for the Auvere FA and DeSOx was 21. 9 and $42.0 \mu \mathrm{m}$, respectively, and for the clinker dust, it was $41.1 \mu \mathrm{m}$ (Table 2). The particles of the Auvere FA had an irregular shape with a porous surface, but the particles of DeSOx, especially the smaller ones, were characterized by a regular spherical shape and smooth surface.

Samples of clay with $40 \%$ of the previously fired at $1050{ }^{\circ} \mathrm{C}$ clay (grog) were used as reference samples. In the blends studied, the grog amount was on the level of $50 \%$ or entirely replaced with OS ash or clinker dust.

A Setaram Labsys Evo 1600 thermoanalyzer (Setaram Instrumentation, Caluire, France) coupled with a Pfeiffer OmniStar Mass Spectrometer (Pfeiffer Vacuum Technology AG, Asslar, Germany) was used for carrying out the experiments under non-isothermal conditions by heating up to $1050{ }^{\circ} \mathrm{C}$ at heating rates of $1.25,2.5,5$ and $10{ }^{\circ} \mathrm{C} \mathrm{min}{ }^{-1}$ in an oxidizing atmosphere containing $79 \% \mathrm{Ar}$ and $21 \% \mathrm{O}_{2}$. Standard $100-\mu \mathrm{L} \mathrm{Pt}$ crucibles were used. The mass of the samples was $12 \pm 0.5 \mathrm{mg}$, and the gas flow was $60 \mathrm{~mL} \mathrm{~min}^{-1}$. For reproducibility, all experiments were performed twice. Prior to the experiments, the equipment was calibrated for temperature readings with calcium oxalate monohydrate.

The contraction-expansion behavior of the samples was studied using a Setaram Setsys 1750 CS Evolution dilatometer (Setaram Instrumentation, Calurie, France) with an alumina probe by heating up to $1050{ }^{\circ} \mathrm{C}$ at a heating rate of $5^{\circ} \mathrm{C} \mathrm{min}^{-1}$. Cylindrical pressed samples with a diameter of $7 \mathrm{~mm}$ and height of $10 \mathrm{~mm}$ were exploited.

FTIR analysis was performed with a Bruker ALPHA (Bruker Corporation, Karlsruhe, Germany) and XRD analysis with a Bruker D8 Advanced Diffractometer (Bruker Corporation, Karlsruhe, Germany) using Ni-filtered $\mathrm{CuK} \alpha$ radiation and collecting data in the range of $2 \theta$ from 10 to $60^{\circ}$. The quantitative mineral composition was determined by full-profile Rietveld analysis using the Siroqant ${ }^{\mathrm{TM}}$ V4 software system $[20,21]$.

The surface observations were carried out with a Jeol JMS-8404A scanning electron microscope (Joel Ltd., Tokyo, Japan). The particle size distribution was measured with a Partica LA-950V2 analyzer (Horiba Ltd., Kyoto, Japan), and the BET SSA and porosity values were measured with a Kelvin 1042 sorptometer (Costech International SRL., Pioltello, Italy).

The acid-alkali resistance test of the fired samples $\left(1050{ }^{\circ} \mathrm{C}, 1 \mathrm{~h}\right)$ was performed in solutions of $\mathrm{HNO}_{3}(\mathrm{pH}=1.0)$ and $\mathrm{NaOH}(\mathrm{pH}=14)$ at room temperature for a GFL3025 agitator (Gessellschaft für Labortechnik mbH, Burgwedel, Germany) (30 cycles per $\mathrm{min}$ ). The mass of the samples was $500 \mathrm{mg}$ in $100 \mathrm{~mL}$ of liquid. After filtration, the solutions were analyzed for their $\mathrm{Ca}^{2+}, \mathrm{Mg}^{2+}$ and $\mathrm{K}^{+}$contents using a Spectra AA atomic absorption spectrophotometer (Varian Inc., Mulgrave, Australia) and their $\mathrm{SO}_{4}{ }^{2-}$ content using a SpectroDirect spectrophotometer (The Tintometer LDT., Dortmund, Germany).

The differential isoconversional Friedman method [22] was applied for calculating the kinetic parameters. After baseline correction and normalization of the TG signals obtained at different heating rates, the data were processed with the AKTS Advanced Thermokinetics software (AKTS AG TECHNOArk, Siders, Switzerland) [23].

\section{Results and Discussion}

\subsection{Thermal and MS Analysis}

The results of the thermal analysis coupled with the mass-spectroscopic (MS) analysis of the evolved gaseous compounds indicated that the emission of hygroscopic and physically bound water at a heating rate of $5^{\circ} \mathrm{C}$ per min occurred up to $220^{\circ} \mathrm{C}$, with corresponding peak minimums in the DTG curves at $86{ }^{\circ} \mathrm{C}$ and $98{ }^{\circ} \mathrm{C}$ and shoulders at $151{ }^{\circ} \mathrm{C}$ and $153{ }^{\circ} \mathrm{C}$ for the Arumetsa and illitic clay, respectively, (Figure 1a) and with corresponding maximums in the water emission profiles at $86^{\circ} \mathrm{C}$ and $78{ }^{\circ} \mathrm{C}$, respectively. 
The dehydroxylation of the clay minerals took place between $300{ }^{\circ} \mathrm{C}$ and $800{ }^{\circ} \mathrm{C}$ but was most intensive around $500^{\circ} \mathrm{C}$ (Figure 1a), with corresponding peaks in the water emission profiles at $480^{\circ} \mathrm{C}$ and $505^{\circ} \mathrm{C}$ for the illitic and Arumetsa clay, respectively (Figure $1 \mathrm{~b}$ ).
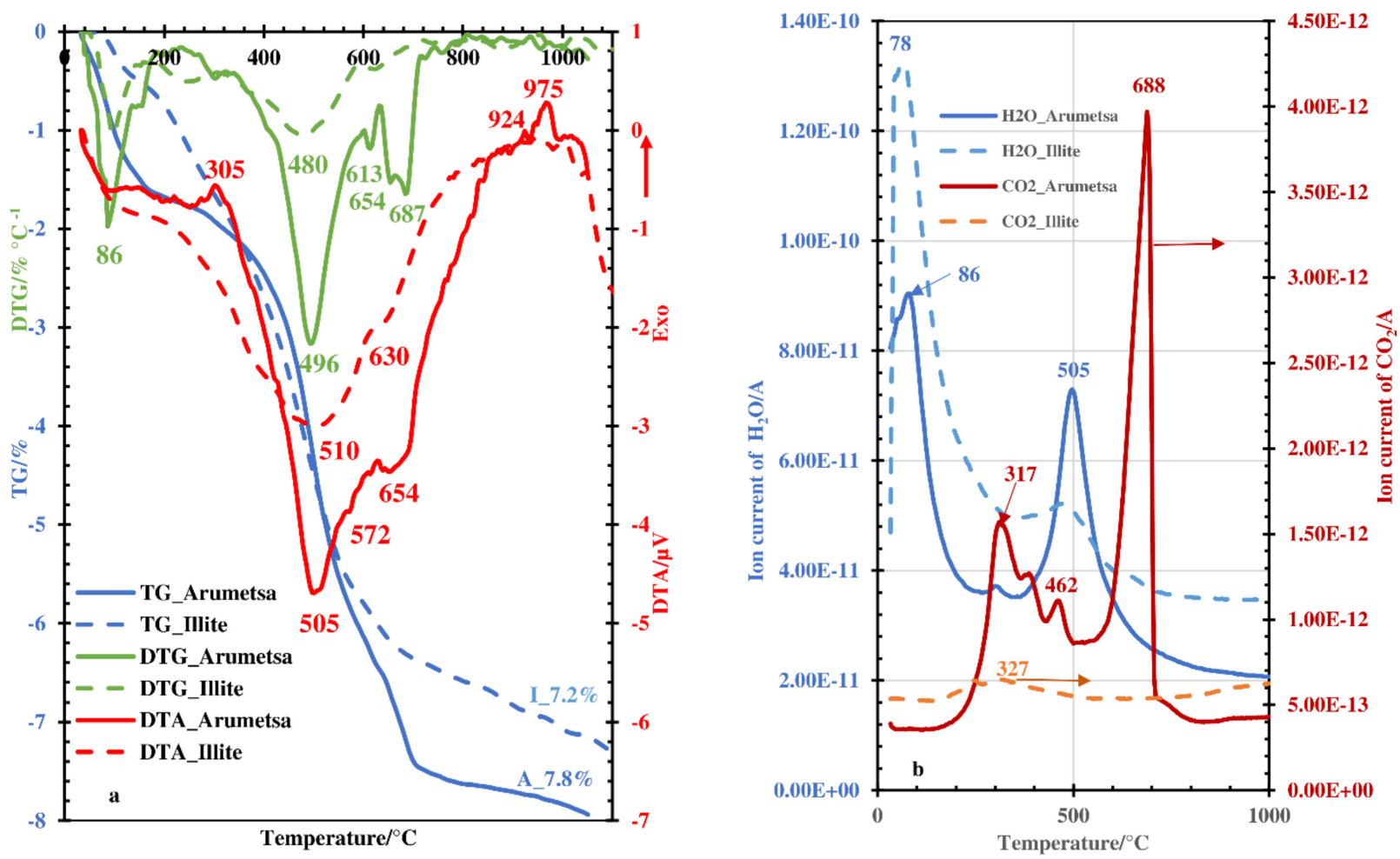

Figure 1. Thermoanalytical curves (a) and emission profiles of $\mathrm{H}_{2} \mathrm{O}$ and $\mathrm{CO}_{2}$ (b) emitted upon thermal treatment of Arumetsa and illitic clay.

The emission of water and, in addition, carbon dioxide up to $500-550{ }^{\circ} \mathrm{C}$ (Figure $1 \mathrm{~b}$ ) was partially caused by thermooxidation of the organic matter contained in clays. The emission of carbon dioxide was more intensive for the Arumetsa clay, in which the content of organic carbon was on the level of $0.32 \%$, and less intensive for the illitic clay, with the content of organic carbon being $0.06 \%$ (Table 2 ).

The $\alpha \rightarrow \beta$ quartz transformation [24,25] for the Arumetsa clay was fixed in the DTA curve, with the small endothermic minimum at $572{ }^{\circ} \mathrm{C}$ and with the shoulder for the illitic clay at $5555^{\circ} \mathrm{C}$ (Figure $\left.1 \mathrm{a}\right)$.

Above $\sim 600^{\circ} \mathrm{C}$, the decomposition of dolomite and calcite in the Arumetsa clay started, corresponding to the endothermic peak with the minimum in the DTA curve at $654{ }^{\circ} \mathrm{C}$ and the shoulder at $685^{\circ} \mathrm{C}$ (Figure 1a), overlapping with the dehydroxylation processes of clay minerals also occurring at these temperatures. In Figure $1 \mathrm{~b}$, there is a well-exposed peak maximum at $688^{\circ} \mathrm{C}$ in the carbon dioxide emission profile of the Arumetsa clay. The exothermic peak with a maximum in the DTA curve of the Arumetsa clay was at $975{ }^{\circ} \mathrm{C}$, and the more modest one for the illitic clay at $924{ }^{\circ} \mathrm{C}$ (Figure 1a) characterizes mullite crystallization $[25,26]$. Upon heating up to $1050^{\circ} \mathrm{C}$, the total mass loss for the Arumetsa clay was 7.8\%, and for illitic clay, it was 7.2\% (Figure 1a).

For thermal treatment of blends with partial or total substitution of grog by ashes or clinker dust additive, certain differences in the thermal behavior could be followed at temperatures above $200-250{ }^{\circ} \mathrm{C}$. In the DTG curves (Figures 2a and 3a), peaks with minimums and with corresponding maximums in the water emission profiles around $380-420{ }^{\circ} \mathrm{C}$ could be fixed (Figures $2 \mathrm{~b}$ and $3 \mathrm{~b}$ ). The peaks were more intensive for blends with ash additives compared with clinker dust additive and more intensive when replacing 
the grog totally. This was caused by decomposition of the portlandite contained in the ashes on the level of $7-10 \%$. In the clinker dust, portlandite was missing (Table 1).
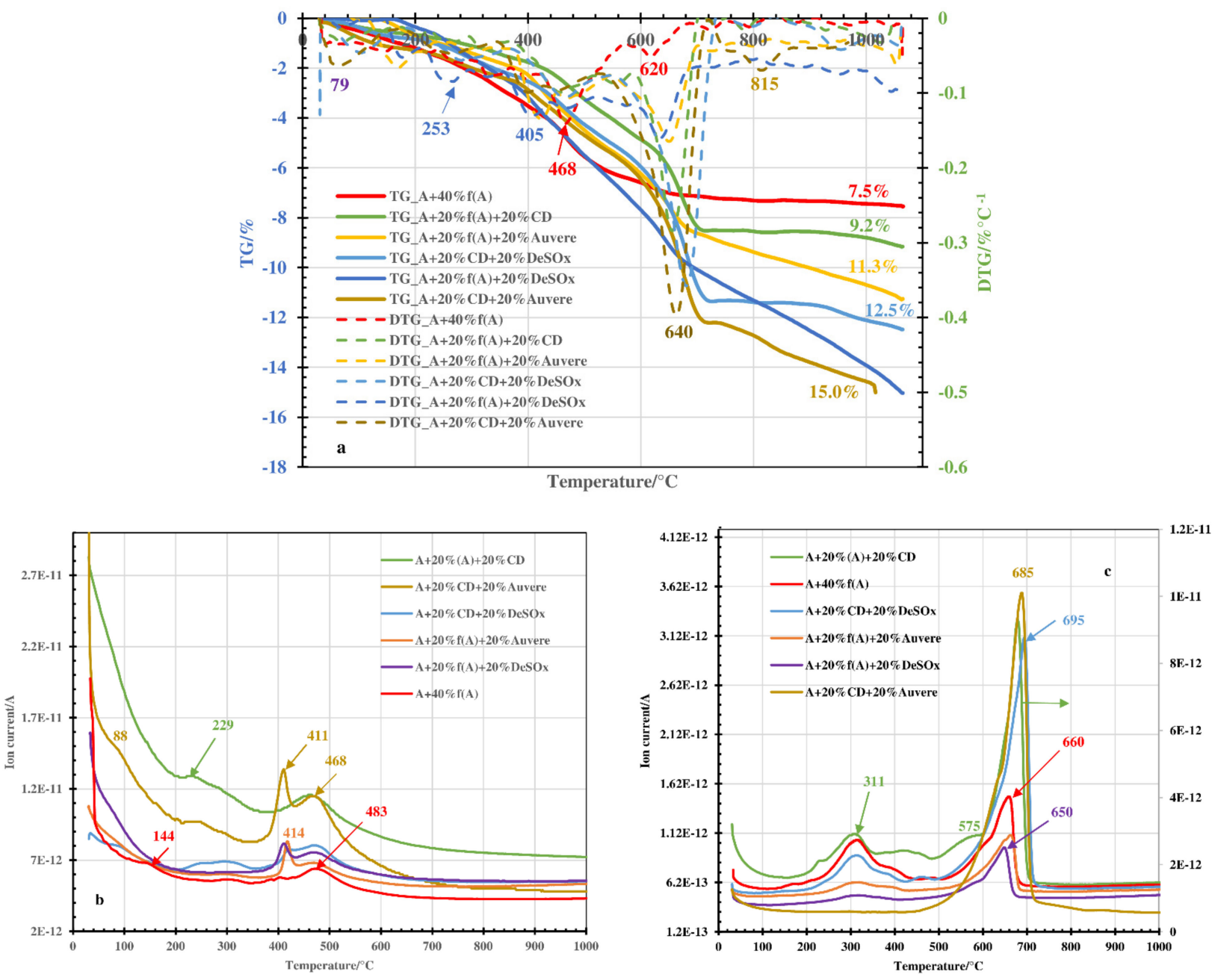

Figure 2. TG and DTG curves (a) and emission profiles of $\mathrm{H}_{2} \mathrm{O}$ (b) and $\mathrm{CO}_{2}$ (c) upon thermal treatment of Arumetsa and illitic clay with different additives to the amount of $20 \%$.

The peak maximums in the $\mathrm{CO}_{2}$ emission profiles in the temperature range of 200 $450{ }^{\circ} \mathrm{C}$ (Figures $2 \mathrm{c}$ and $3 \mathrm{c}$ ) resulting from thermooxidation of organic matter in the clays were, as a rule, less intensive compared with the pure clay samples (Figure 1b) and less intensive for blends based on illitic clay compared with blends based on Arumetsa clay (Figure 3c). The reasons for this are, first of all, that carbon dioxide formed there is partially bound into the solid by $\mathrm{Ca}(\mathrm{OH})_{2}$ or free $\mathrm{CaO}$ formed upon decomposition of portlandite, with the formation of secondary calcite $[27,28]$, and second that the content of organics in the illitic clay was much lower than that in the Arumetsa clay (Table 2). At temperatures higher than $550{ }^{\circ} \mathrm{C}$, on the contrary, the $\mathrm{CO}_{2}$ emission profiles were more intensive compared with those of the pure clays due to the decomposition of carbonates contained in the additives (Table 1) and of secondary $\mathrm{CaCO}_{3}$ formed at lower temperatures. Especially intensive was the $\mathrm{CO}_{2}$ profile for blends containing clinker dust additive (Figures $2 \mathrm{c}$ and $3 \mathrm{c}$ ), due to the very high content of calcite in the clinker dust (Table 1). Due to the high content of calcite $(47.3 \%)$ in the clinker dust, the blends were also characterized with the highest mass loss upon heating up to $1050{ }^{\circ} \mathrm{C}: 15 \%$ (Figure 2a) and 17\% (Figure 3a) for partial or full replacement of the grog with clinker dust, respectively. 

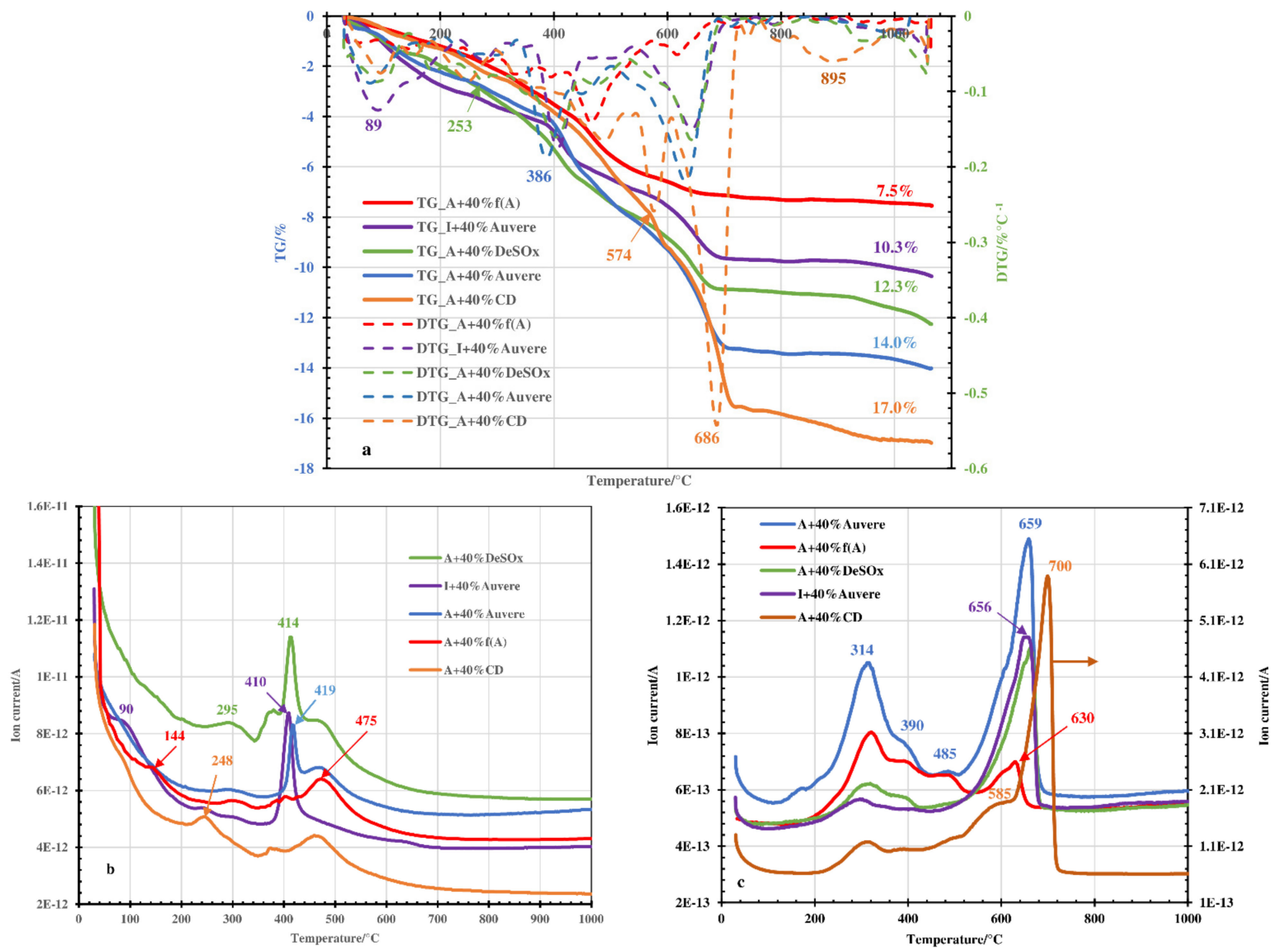

Figure 3. TG and DTG curves (a) and emission profiles of $\mathrm{H}_{2} \mathrm{O}(\mathbf{b})$ and $\mathrm{CO}_{2}$ (c) upon thermal treatment of Arumetsa and illitic clay with different additives to the amount of $40 \%$.

\subsection{Thermodilatometry, Physical-Chemical Characteristics and Morphology}

The results of the dilatometric measurements up to $1050{ }^{\circ} \mathrm{C}$ are presented in Figure $4 \mathrm{a}$, with the enlarged one in Figure $4 \mathrm{~b}$. According to the line of the Arumetsa basic sample (Arumetsa clay $+40 \%$ grog), up to $180-200{ }^{\circ} \mathrm{C}$, shrinkage of the sample of around $-0.08 \%$ caused by the emission of physically bound water could be followed. Then, permanent expansion took place upon heating up to $580^{\circ} \mathrm{C}$ (to the level of $-0.01 \%$ ). Between these temperatures, the dehydroxylation of clay minerals started and continued, and thermooxidation of the organic matter took place, causing an increase in the SSA and porosity of the samples together with the expansion of the ceramic body. A steeper increase (to the level of $0.05 \%$ ) in the thermodilatometric line between $580-610^{\circ} \mathrm{C}$ was caused by $\alpha-\beta$ transition of the quartz. Between 620 and $780^{\circ} \mathrm{C}$, contraction of the body took place, caused by the ongoing dehydroxylation processes of the clay minerals and decomposition of the carbonates. Then, at higher temperatures, a two-step contraction could be followed to the level of $-7.2 \%$ at $1050{ }^{\circ} \mathrm{C}$, caused by starting the formation of the liquid phase of the dehydroxylated clay minerals. The content of the amorphous phase in the thermally treated Arumetsa clay up to $1050{ }^{\circ} \mathrm{C}$ was $44.7 \%$. 

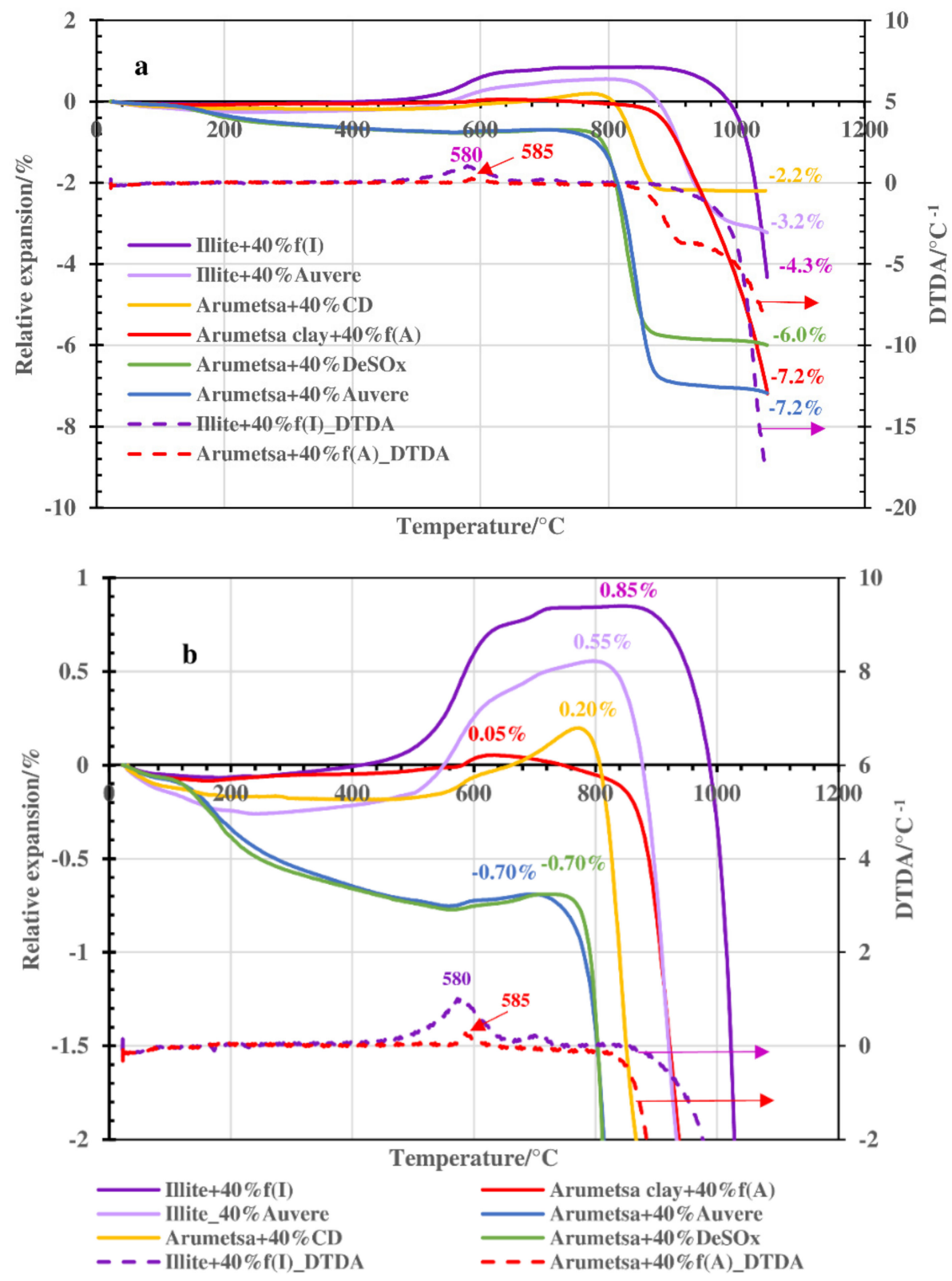

Figure 4. Thermodilatometric curves of Arumetsa and illitic clay with different additives heated up to $1050{ }^{\circ} \mathrm{C}$ : (a) up to $1050{ }^{\circ} \mathrm{C}$ and (b) up to $100{ }^{\circ} \mathrm{C}$ (enlarged).

Auvere FA and DeSOx additives to Arumetsa clay similarly influenced the dilatometry results of these blends. There, a deeper shrinkage of the ceramic body compared with the basic blend upon heating up to $200-240{ }^{\circ} \mathrm{C}$ could be followed to the level of $-0.42 \%$ and $-0.40 \%$ for blends with DeSOx and Auvere FA, respectively (Figure $4 \mathrm{~b}$ ). Then, a slow but permanent shrinkage followed, with a small, deep increase at around $590{ }^{\circ} \mathrm{C}(\alpha-\beta$ transition of the quartz) in the dilatometric line and, after that, a continuing increase leveling at $-0.70 \%$ up to $700-720{ }^{\circ} \mathrm{C}$ for both blends. This can be explained by the quite similar contents of lime and portlandite in these ashes and lower organic contents compared with the basic blend, which are involved in different chemical reactions at these temperatures. Between 720 and $880{ }^{\circ} \mathrm{C}$, deep contraction of the ceramic bodies took place to the level of $-5.8 \%$ and $-6.8 \%$ for the blends with DeSOx and Auvere FA, respectively. Then, only small additional contraction could be followed up to $1050{ }^{\circ} \mathrm{C}$ (Figure $4 \mathrm{a}$ ). 
The blend of Arumetsa clay with clinker dust had only slightly more extensive shrinkage upon heating up to $200{ }^{\circ} \mathrm{C}$ compared with the basic body (up to $-0.21 \%$ ) (Figure 4 ), caused by the emission of physically bound water. Between 200 and $500{ }^{\circ} \mathrm{C}$, no changes were observed, but then a permanent expansion took place up to $780{ }^{\circ} \mathrm{C}$ to the level of $0.20 \%$, with a small rapid one around $580{ }^{\circ} \mathrm{C}$ caused by the $\alpha-\beta$ transition of the quartz. Deeper expansion of the ceramic body at $600-780{ }^{\circ} \mathrm{C}$ was most likely caused by the dehydroxylation of clay minerals (Table 1). Between 800 and $900{ }^{\circ} \mathrm{C}$, a deep shrinkage of the ceramic bodies (up to $-2.2 \%$ ) followed, with no additional changes up to $1050{ }^{\circ} \mathrm{C}$.

Illitic clay with $40 \%$ grog heated up to $400{ }^{\circ} \mathrm{C}$ followed the pattern of Arumetsa clay $+40 \%$ grog, but between $400{ }^{\circ} \mathrm{C}$ and $750{ }^{\circ} \mathrm{C}$, more intensive expansion of the body took place, being up to $0.85 \%$ with a shoulder in the dilatometric curve at around $700{ }^{\circ} \mathrm{C}$ caused by two-step dehydroxylation of the illitic clay minerals. Above $900{ }^{\circ} \mathrm{C}$, a deep contraction of the ceramic bodies $\left(-4.3 \%\right.$ at $\left.1050{ }^{\circ} \mathrm{C}\right)$ caused by destruction of the layered structure of the clay minerals took place, followed by formation of a liquid phase. These differences in the TDA curves of the blends based on Arumetsa and illitic clay could be explained by differences in the mineralogical compositions of the clays. Dehydroxylation of kaolin in the Arumetsa clay stopped at lower temperatures (around $700{ }^{\circ} \mathrm{C}$ ) $[29,30]$ compared with the illitic clay minerals (around 800-900 ${ }^{\circ} \mathrm{C}$ ) [31-33].

Illitic clay with Auvere ash additive mainly follows the pattern of illitic clay $+40 \%$ grog, but up to $250-300{ }^{\circ} \mathrm{C}$, a more intensive contraction of the ceramic bodies $(-0.26 \%)$ could be followed compared with the basic blend $(-0.08 \%)$, caused by the higher content of physically bound water in the previously hydrated Auvere ash. At these temperatures, the expansion of the ceramic bodies started reaching up to $0.55 \%$ at $800-820{ }^{\circ} \mathrm{C}$, with the following deep contraction of the sample reaching up to $-3.2 \%$ at $1050{ }^{\circ} \mathrm{C}$, caused by the formation of a liquid phase (Figure $4 a$ ).

These results for the dilatometric measurements were in accord with changes in the SSA and porosity values of the samples treated thermally at different temperatures (Figure 5). For the blends based on Arumetsa clay treated at $250{ }^{\circ} \mathrm{C}$, the changes in the SSA values were more extensive, being on the level of 7-11 units compared with those based on illitic clay (4-5 units) (Figure 5a). The changes in porosity were more modest for all samples except for the clinker dust additive, being on the level of 4-6 units (Figure 5b). The most extensive influence could be seen by replacing half of the grog with the clinker dust additive. For example, for Arumetsa clay with 20\% clinker dust, the SSA decreased from 20.3 down to $10.4 \mathrm{~m}^{2} \mathrm{~g}^{-1}$ (Figure 5a), and the porosity dropped from 32.1 to $20.6 \mathrm{~mm}^{3} \mathrm{~g}^{-1}$ (Figure $5 \mathrm{~b}$ ). These changes were caused by the complete emission of physically bound water followed by tightening of the structure of the samples.

An increase in the treating temperature up to $550{ }^{\circ} \mathrm{C}$ brought about an increase in the SSA and porosity of the samples up to the level of the initial samples. This was caused by dehydroxylation of the clay minerals and the decomposition of portlandite, making the structure of the samples more porous. At $800{ }^{\circ} \mathrm{C}$, the different additives studied caused a proportional decrease in the porosity of the samples, disappearing almost totally at $1050{ }^{\circ} \mathrm{C}$ (Figure 5a,b).

When replacing all the grog with clinker dust, the SSA and porosity changed differently compared with the other blends (Figure 5a,b), which was caused by the mineralogical composition of the clinker dust: a high content of carbonates and missing amorphous phase (Table 1).

Therefore, the changes in the SSAs and porosities of the studied blends depended on the differences in the characteristics of the origin clays but, first and foremost, on the origin of the additives used. 

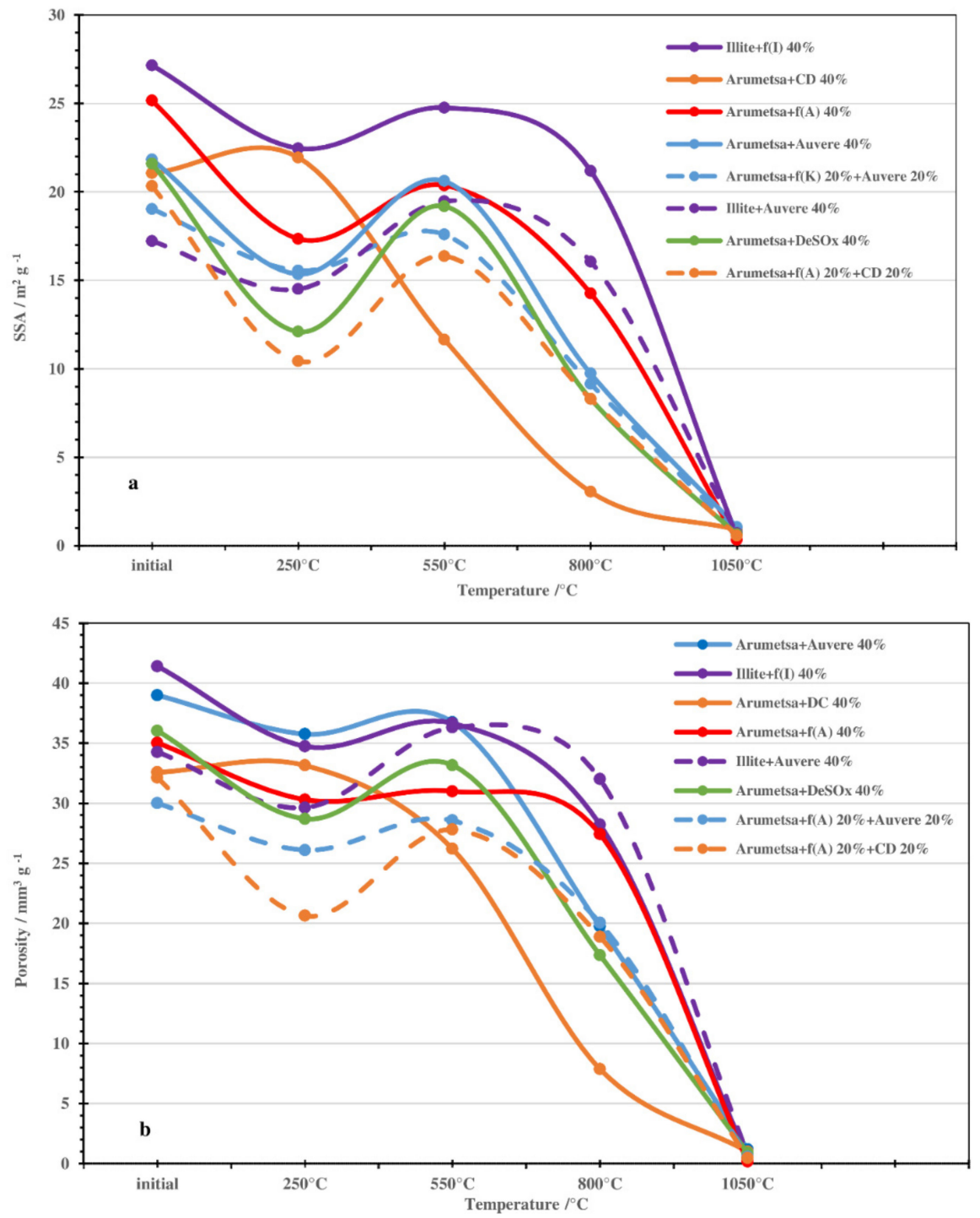

Figure 5. Changes in SSA (a) and porosity (b) values of initial and thermally treated blends with different additives.

The particle surfaces of the Arumetsa (SSA: $0.34 \mathrm{~m}^{2} \mathrm{~g}^{-1}$; porosity: $0.18 \mathrm{~mm}^{3} \mathrm{~g}^{-1}$ ) (Figure 6a) and illitic clay (SSA: $0.59 \mathrm{~m}^{2} \mathrm{~g}^{-1}$; porosity: $0.47 \mathrm{~mm}^{3} \mathrm{~g}^{-1}$ ) (Figure 6e) treated thermally at $1050{ }^{\circ} \mathrm{C}$ were almost completely covered with a glassy phase. Auvere FA, DeSOx and clinker dust additives improved the structures of the samples treated at $1050{ }^{\circ} \mathrm{C}$ by increasing the melting points of the blends, with a following increase in the porosity and SSA values of the samples and a decrease in the melting points on the surfaces of the particles. For example, for the blend of Arumetsa clay with 40\% Auvere FA (Figure 6b), the SSA and $V_{\text {pores }}$ values were $1.06 \mathrm{~m}^{2} \mathrm{~g}^{-1}$ and $1.18 \mathrm{~mm}^{3} \mathrm{~g}^{-1}$ (these values for illitic clay with $40 \%$ Auvere FA were $1.02 \mathrm{~m}^{2} \mathrm{~g}^{-1}$ and $1.20 \mathrm{~mm}^{3} \mathrm{~g}^{-1}$, respectively (Figure $6 \mathrm{f}$ )), while those with $40 \%$ DeSOx were $0.65 \mathrm{~m}^{2} \mathrm{~g}^{-1}$ and $0.90 \mathrm{~mm}^{3} \mathrm{~g}^{-1}$ (Figure $6 \mathrm{c}$ ) and those with $40 \%$ clinker dust were $0.90 \mathrm{~m}^{2} \mathrm{~g}^{-1}$ and $0.99 \mathrm{~mm}^{3} \mathrm{~g}^{-1}$ (Figure $6 \mathrm{~d}$ ), respectively. 


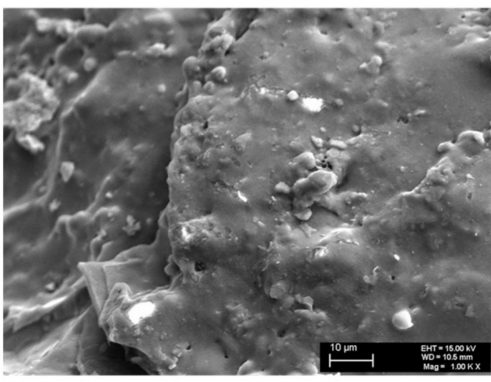

a

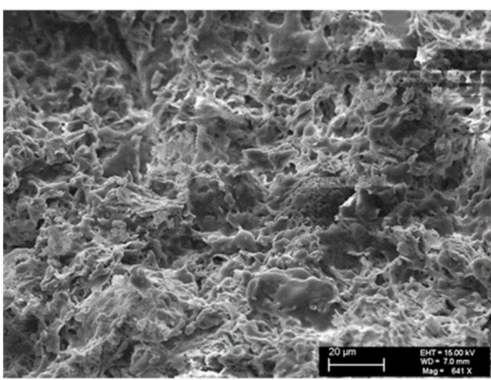

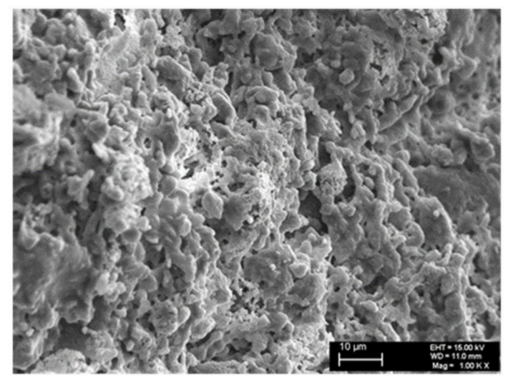

b

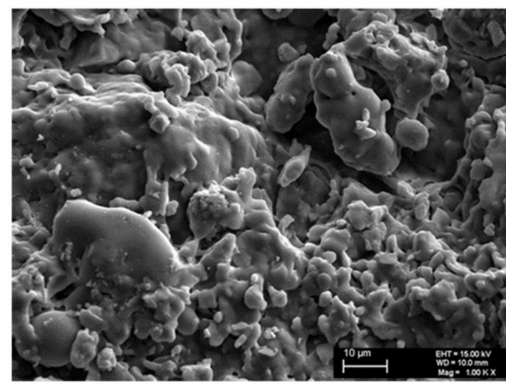

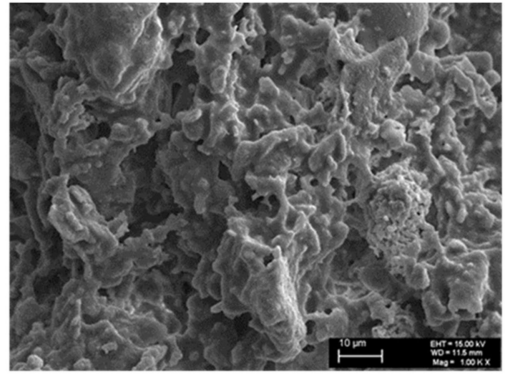

c

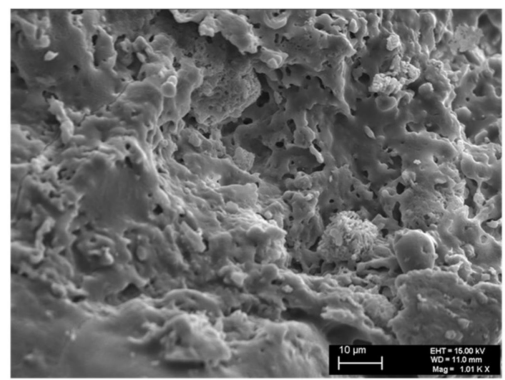

Figure 6. SEM photos of the samples thermally treated at $1050{ }^{\circ} \mathrm{C}$ : (a) Arumetsa $+40 \% \mathrm{f}(\mathrm{A})$, (b) A $+40 \%$ Auvere FA, (c) A + 40\%DeSOx, (d) A + 40\%CD, (e) Illite $+40 \% \mathrm{f}(\mathrm{I})$ and (f) $\mathrm{I}+40 \%$ Auvere (magnification: $\mathbf{a}-\mathbf{c}, \mathbf{e}, \mathbf{f}=1000^{\mathrm{x}}, \mathbf{d}=640^{\mathrm{x}}$ ).

\subsection{FTIR and XRD Analysis: Acid-Alkali Resistance Test}

For characterization of the influence of the OS ash and clinker dust additives on the mineralogical compositions of the initial blends as well as the influence of the treating temperature on it, the FTIR spectroscopic method was applied. The initial blends and samples thermally treated up to $1050{ }^{\circ} \mathrm{C}$ were also analyzed using XRD.

The differences in the intensities of the different absorption bands for the initial blends, depending on the compositions of the samples, can be followed in Figure $7 \mathrm{a}, \mathrm{b}$. There were fixed absorption bands characteristic to $\mathrm{OH}^{-1}$ (peak maximums at 3690 and $\left.3618 \mathrm{~cm}^{-1}\right)$ [34-37], $\mathrm{H}_{2} \mathrm{O}\left(1635 \mathrm{~cm}^{-1}\right)$ [34,35], $\mathrm{CO}_{3}^{-2}\left(1430 \mathrm{~cm}^{-1}\right.$ and $\left.875 \mathrm{~cm}^{-1}\right)$ [38,39] and $\mathrm{SO}_{4}{ }^{2-}\left(1160 \mathrm{~cm}^{-1}, 1130 \mathrm{~cm}^{-1}, 679 \mathrm{~cm}^{-1}\right.$ and $\left.598 \mathrm{~cm}^{-1}\right)$ [40]. Absorption bands characteristic to different vibrations in the silicate and alumosilicate groups were also exposed $(\mathrm{Si}-\mathrm{O}(\mathrm{Si})$ $\left(1090 \mathrm{~cm}^{-1}\right)$ [36-38,40-42], Si-O(Al) $\left(1000 \mathrm{~cm}^{-1}\right)$ [37,40], Al-OH $\left(914 \mathrm{~cm}^{-1}\right)$ [36,40,41], Al-O$\mathrm{Si}\left(522 \mathrm{~cm}^{-1}\right)$ [35,39], O-Si-O $\left(696 \mathrm{~cm}^{-1}\right.$ and $\left.\left.465 \mathrm{~cm}^{-1}\right)[35,39,40,42,43]\right)$ and a double band characteristic to quartz $\left(798 \mathrm{~cm}^{-1}\right.$ and $\left.777 \mathrm{~cm}^{-1}\right)$ [35,39,40,42,43]. Given that, the influence of the clinker dust additive was the most expressive, caused by the highest content of calcite and arcanite and also by the content of some clay minerals (Table 1 ).

All these bands were fixed in the FTIR spectra of the samples treated thermally at $250{ }^{\circ} \mathrm{C}$, and only the band characteristic to the $\mathrm{H}_{2} \mathrm{O}$ group $\left(1635 \mathrm{~cm}^{-1}\right)$ was less intensive (Figure 8a). At $550{ }^{\circ} \mathrm{C}$, the absorption bands characteristic to the $\mathrm{H}_{2} \mathrm{O}\left(1635 \mathrm{~cm}^{-1}\right)$ groups were not present, and the intensities of those characteristic to $\mathrm{OH}^{-1}$ vibration $\left(3690 \mathrm{~cm}^{-1}\right.$ and $3618 \mathrm{~cm}^{-1}$ ) were remarkably lower.

According to the decomposition of carbonates between 600 and $800{ }^{\circ} \mathrm{C}$, the bands characteristic to $\mathrm{CO}_{3}{ }^{-2}\left(1430 \mathrm{~cm}^{-1}\right.$ and $\left.875 \mathrm{~cm}^{-1}\right)$ disappeared in the FTIR spectra. The decrease in the intensities of different silicate (alumosilicate) bands like $\mathrm{Si}-\mathrm{O}(\mathrm{Al})\left(1000 \mathrm{~cm}^{-1}\right), \mathrm{Al}-\mathrm{O}-\mathrm{Si}$ $\left(522 \mathrm{~cm}^{-1}\right.$, where for the blend with clinker dust additive, only a shoulder remained) and O-Si-O bending vibration $\left(465 \mathrm{~cm}^{-1}\right)$ could also be followed, being especially remarkable at $1050{ }^{\circ} \mathrm{C}$ (Figure $8 \mathrm{a}, \mathrm{b}$ ). This was caused by the interactions between the primary silicates and periclase as well as the free $\mathrm{CaO}$ with the formation of secondary silicates. For the natural clays, a new band appeared at around $1050 \mathrm{~cm}^{-1}$, being characteristic to Si-O stretching vibration $[36,37,42]$, and a band at $900 \mathrm{~cm}^{-1}$ for the samples with additives that 
was characteristic to $\mathrm{Al}-\mathrm{O}(\mathrm{Si})$ vibration [41]. In the FTIR spectra, for all the samples studied, a shoulder at $1010 \mathrm{~cm}^{-1}$ characterizing the $\mathrm{Si}-\mathrm{O}(\mathrm{Al})$ asymmetric stretching vibration in the aluminosilicate structure $[38,41]$ was still exposed.
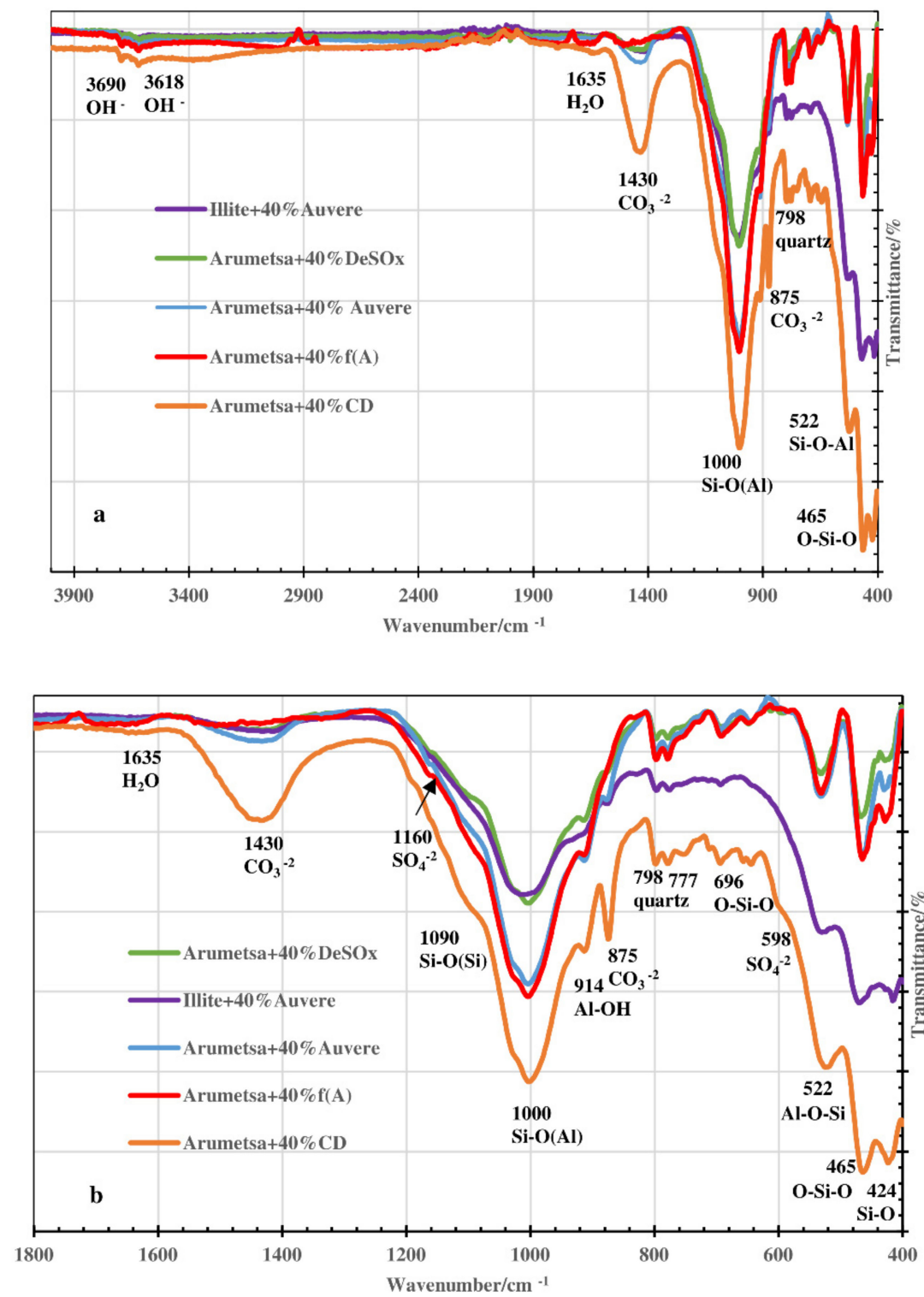

Figure 7. FTIR spectra of initial blends based on Arumetsa and illitic clay with $40 \%$ of different additives. (a) Wavenumber range of $4000-400 \mathrm{~cm}^{-1}$. (b) Wavenumber range of $1800-400 \mathrm{~cm}^{-1}$. 

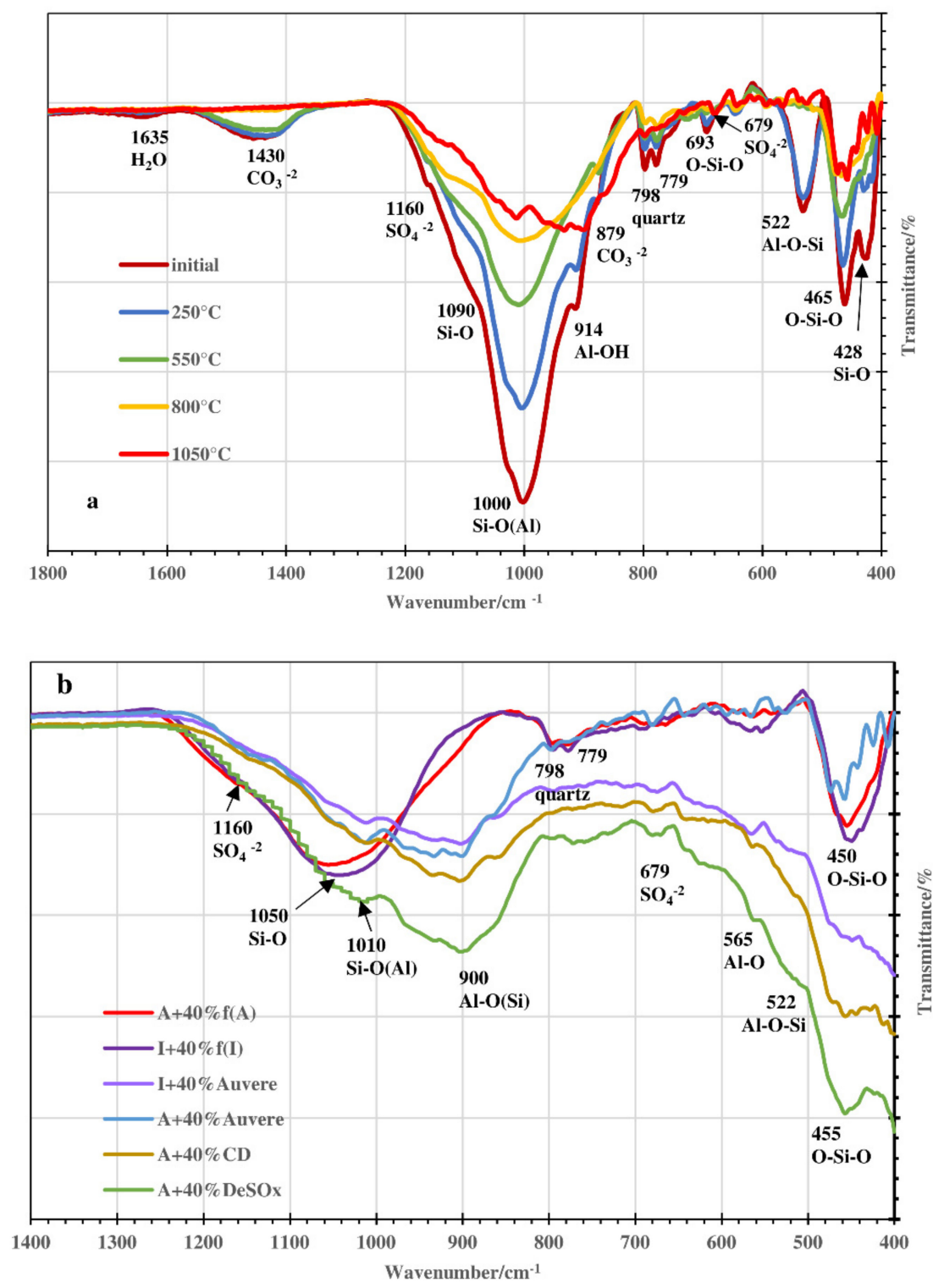

Figure 8. FTIR spectra of blend based on Arumetsa clay with $40 \%$ Auvere FA, $\mathrm{H}$ thermally treated at different temperatures (a) and blends based on Arumetsa and illitic clay with different additives thermally treated at $1050^{\circ} \mathrm{C}(\mathbf{b})$.

The results of the XRD analysis of the initial samples (clay $+40 \%$ fired clay) heated for $1 \mathrm{~h}$ at $1050{ }^{\circ} \mathrm{C}$ indicated the formation of an amorphous phase on the level of $44.7 \%$ and $50.3 \%$ based on Arumetsa and illitic clay, respectively. The formation of spinel to the level of $10.7 \%$ and $5.8 \%$, mullite at $11.6 \%$ and $3.8 \%$, sanidin at $6.6 \%$ and $18.5 \%$ and sillimanite at $0.8 \%$ and $2.3 \%$ in the samples based on Arumetsa and illitic clay, respectively, were fixed as the main secondary silicates. The content of quartz was on the level of $18.3 \%$ and $16.8 \%$ in the fired Arumetsa and illitic clay, respectively (Table 3). Some amount of leucite (0.9\% in the fired Arumetsa clay) and wollastonite (0.5\% in the illitic clay) was fixed, as well as periclase and hematite in the Arumetsa clay and enstantite in the illitic clay fired at $1050{ }^{\circ} \mathrm{C}$ (Table 3). 
Table 3. Mineralogical composition (\%) of thermally treated samples at $1050{ }^{\circ} \mathrm{C}$.

\begin{tabular}{|c|c|c|c|c|c|c|c|c|}
\hline $\begin{array}{c}\text { Compound } \\
\text { or } \\
\text { Formula }\end{array}$ & $\begin{array}{c}\text { Arumetsa(A) } \\
60 \% \\
+40 \% \text { f(A) }\end{array}$ & $\begin{array}{c}\text { A } 60 \%+40 \% \\
\text { Auvere FA }\end{array}$ & $\begin{array}{c}\mathrm{A} 60 \%+40 \% \\
\text { DeSOx }\end{array}$ & $\begin{array}{c}\mathrm{A} 60 \% \\
+40 \% \mathrm{CD}\end{array}$ & $\begin{array}{l}\text { Illite(I) } 60 \% \\
+40 \% \text { f(I) }\end{array}$ & $\begin{array}{c}\mathrm{I} 60 \%+40 \% \\
\text { Auvere FA }\end{array}$ & $\begin{array}{c}\mathrm{I} 60 \%+40 \% \\
\text { DeSOx }\end{array}$ & $\begin{array}{c}\mathrm{I} 60 \%+40 \% \\
\mathrm{CD}\end{array}$ \\
\hline $\begin{array}{l}\text { Amorphous } \\
\text { phase }\end{array}$ & 44.7 & 17.20 & 23.70 & 14.10 & 50.30 & 22.20 & 21.90 & 18.30 \\
\hline Quartz, $\mathrm{SiO}_{2}$ & 18.27 & 8.78 & 5.65 & 5.67 & 16.75 & 10.04 & 7.65 & 6.05 \\
\hline $\begin{array}{l}\text { Sillimanite, } \\
\mathrm{Al}_{2} \mathrm{SiO}_{5}\end{array}$ & 0.77 & - & 0.23 & 1.29 & 2.29 & 0.62 & 0.78 & - \\
\hline $\begin{array}{c}\text { Diopside, } \\
\mathrm{CaMgSi}_{2} \mathrm{O}_{6}\end{array}$ & - & 5.80 & 5.57 & 9.36 & - & 1.40 & 1.59 & 2.06 \\
\hline $\begin{array}{l}\text { Anhydrite, } \\
\mathrm{Ca}\left(\mathrm{SO}_{4}\right)_{2}\end{array}$ & - & 1.74 & 0.53 & - & - & 1.48 & 1.33 & 2.37 \\
\hline $\begin{array}{l}\text { Wollastonite, } \\
\mathrm{CaSiO}_{3}\end{array}$ & - & 5.63 & 5.19 & 6.18 & 0.50 & 7.62 & 7.97 & 8.58 \\
\hline $\begin{array}{l}\text { Akermanite, } \\
\mathrm{Ca}_{2} \mathrm{Mg}\left(\mathrm{Si}_{2} \mathrm{O}_{7}\right)\end{array}$ & - & 14.16 & 11.37 & 18.47 & - & 15.33 & 9.37 & 11.05 \\
\hline $\begin{array}{c}\text { Periclase, } \\
\mathrm{MgO}\end{array}$ & 1.05 & 0.58 & 2.44 & 0.09 & - & - & - & - \\
\hline $\begin{array}{l}\text { Hematite, } \\
\mathrm{Fe}_{2} \mathrm{O}_{3}\end{array}$ & 5.35 & 5.46 & 5.04 & 1.29 & 0.55 & 2.85 & 3.51 & 3.07 \\
\hline $\begin{array}{c}\text { Leucite, } \\
\mathrm{K}\left(\mathrm{AlSi}_{2} \mathrm{O}_{6}\right)\end{array}$ & 0.88 & 6.87 & 9.38 & 12.38 & - & 14.39 & 13.90 & 19.77 \\
\hline $\begin{array}{c}\text { Spinel, } \\
\mathrm{MgAl}_{2} \mathrm{O}_{3}\end{array}$ & 10.71 & 5.22 & 6.41 & 9.79 & 5.81 & - & - & - \\
\hline $\begin{array}{l}\text { Enstatite, } \\
\mathrm{MgSiO}_{3}\end{array}$ & - & 5.22 & 4.88 & 6.01 & 1.64 & 5.68 & 5.86 & 5.56 \\
\hline $\begin{array}{c}\text { Plagioclase, } \\
\mathrm{NaCaAlSi}_{3} \mathrm{O}_{6}\end{array}$ & - & 0.75 & - & 1.80 & - & - & - & - \\
\hline $\begin{array}{c}\text { Mullite, } \\
\mathrm{Al}_{6} \mathrm{Si}_{2} \mathrm{O}_{13}\end{array}$ & 11.59 & 15.07 & 5.88 & 1.72 & 3.78 & 2.20 & 1.87 & 1.34 \\
\hline $\begin{array}{c}\text { Sanidin, } \\
\mathrm{KAlSi}_{3} \mathrm{O}_{8}\end{array}$ & 6.57 & 2.90 & 6.56 & 7.22 & 18.49 & 5.03 & 2.66 & 6.63 \\
\hline $\begin{array}{c}\text { Anorthite, } \\
\mathrm{CaAl}_{2} \mathrm{Si}_{2} \mathrm{O}_{8}\end{array}$ & - & 4.64 & 7.17 & 4.47 & - & 11.51 & 21.01 & 15.20 \\
\hline
\end{tabular}

In the blends fired at $1050{ }^{\circ} \mathrm{C}$, the formation of the amorphous phase decreased remarkably to the level of $14-24 \%$ and $18-22 \%$ based on the Arumetsa and illitic clay, respectively, in addition to decreasing the contents of sanidin, mullite and spinel compared with the fired clay samples. On the contrary, the formation of many new secondary silicates and alumosilicates like akermanite on the level of $11.4-18.5 \%$ and $9.4-15.3 \%$, as well as leucite (6.9-12.4\% and 13.9-19.8), diopside (5.7-9.4\% and 1.4-2.1\%), anorthite (4.5-7.2\% and $11.5-21.0 \%$ ), wollastonite (5.2-6.2\% and 7.6-8.6\%) and enstantite (4.9-6.0\% and 5.6-5.9\%) based on the Arumetsa and illitic clay, respectively, could be followed. The content of quartz decreased, being between $5.7 \%$ and $8.8 \%$ in the blends based on Arumetsa clay and between $6.1 \%$ and $10.0 \%$ for the illitic clay, caused by the active participation of it in the formation of different secondary silicates. The higher content of potassium in the clinker dust compared with DeSOx and Auvere FA assisted the formation of leucite $\left(\mathrm{K}\left(\mathrm{AlSi}_{2} \mathrm{O}_{6}\right)\right)$ and sanidin $\left(\mathrm{KAlSi}_{3} \mathrm{O}_{8}\right)$ upon thermal treatment of the blends containing clinker dust (Table 3).

The content of anhydrite in the thermally treated samples decreased compared with the initial samples (Table 1), and the arcanite content was not fixed at all (Table 3). Missing $\mathrm{SO}_{2}$ in the evolved gases (Figure 3) indicated that anhydrite was transferred partially and the arcanite was transferred completely into the amorphous phase upon thermal treatment of the samples. 
The results of the acid-alkali resistance test of the ceramic bodies fired at $1050{ }^{\circ} \mathrm{C}$ are presented in Table 4. The relative leachability values of $\mathrm{Ca}^{2+}, \mathrm{Mg}^{2+}, \mathrm{K}^{+}$(presented as $\mathrm{CaO}$, $\mathrm{MgO}$ and $\mathrm{K}_{2} \mathrm{O}$ ) and $\mathrm{SO}_{4}{ }^{2-}$ were calculated according to the following equation:

Leachability, $\%=($ mass in solution, $\mathrm{mg} / \mathrm{mass}$ in solid, $\mathrm{mg}) \times 100$

In an acidic environment, the OS ash and clinker dust additives increased the relative leachability of the studied ions quite drastically, and as a rule, the leaching of $\mathrm{Ca}^{2+} \mathrm{and}^{2+}$ was more intensive, being on the level of $8.8-11.1 \%$ and $1.2-7.2 \%$, respectively, from the ceramic bodies based on illitic clay, instead of 5.0-9.1\% and $0.8-2.0 \%$, respectively, for the blends based on Arumetsa clay. Leaching of $\mathrm{K}^{+}$was practically on the same level for both clay compositions (between $11.1 \%$ and $16.3 \%$ ), and that of $\mathrm{SO}_{4}{ }^{2-}$ varied depending on both the basic clays and additives (Table 4). A more considerable increase in the leachability of the ions studied was fixed for the blends with the clinker dust additive, differentiated by their mineralogical compositions from the other thermally treated blends: a higher content of diopside, leucide and akermanite and a lower content of the amorphous phase (Table 3).

Table 4. Relative leachability of $\mathrm{CaO}, \mathrm{MgO}, \mathrm{K}_{2} \mathrm{O}$ and $\mathrm{SO}_{4}{ }^{-2}(\%)$ from thermally treated samples $(1 \mathrm{~h}$ at $1050{ }^{\circ} \mathrm{C}$ ) in $10 \%$ water solution of $\mathrm{HNO}_{3}$ and $\mathrm{NaOH}$.

\begin{tabular}{|c|c|c|c|c|}
\hline \multirow{2}{*}{ Sample } & \multicolumn{4}{|c|}{$10 \% \mathrm{HNO}_{3}$} \\
\hline & $\mathrm{CaO}$ & $\mathrm{MgO}$ & $\mathrm{K}_{2} \mathrm{O}$ & $\mathrm{SO}_{4}-2$ \\
\hline Arumetsa(A) $+40 \% \mathrm{f}(\mathrm{A})$ & 0.83 & 0.18 & 0.03 & 7.47 \\
\hline $\mathrm{A}+40 \%$ Auvere FA & 5.03 & 1.32 & 11.07 & 0.44 \\
\hline $\mathrm{A}+40 \% \mathrm{DeSO}$ & 6.04 & 0.80 & 15.67 & 3.75 \\
\hline$A+40 \% C D$ & 9.11 & 2.04 & 16.33 & 17.81 \\
\hline Illite(I) $+40 \% \mathrm{f}(\mathrm{I})$ & 2.26 & 0.15 & 0.07 & 7.52 \\
\hline $\mathrm{I}+40 \%$ Auvere FA & 8.81 & 7.23 & 11.68 & 0.45 \\
\hline $\mathrm{I}+40 \% \mathrm{DeSOx}$ & 8.66 & 1.22 & 15.11 & 14.00 \\
\hline $\mathrm{I}+40 \% \mathrm{CD}$ & 11.07 & 5.91 & 15.09 & 12.86 \\
\hline \multicolumn{5}{|c|}{$10 \% \mathrm{NaOH}$} \\
\hline Arumetsa(A) $+40 \% \mathrm{f}(\mathrm{A})$ & 3.74 & 0.014 & 4.48 & 96.42 \\
\hline $\mathrm{A}+40 \%$ Auvere FA & 0.35 & 0.012 & 5.64 & 4.32 \\
\hline $\mathrm{A}+40 \% \mathrm{DeSOx}$ & 0.72 & 0.008 & 5.39 & 0.57 \\
\hline $\mathrm{A}+40 \% \mathrm{CD}$ & 0.72 & 0.005 & 8.05 & 0.93 \\
\hline Illite(I) + 40\%f(I) & 0.93 & 0.072 & 2.16 & 56.18 \\
\hline $\mathrm{I}+40 \%$ Auvere FA & 0.55 & 0.029 & 3.51 & 2.93 \\
\hline $\mathrm{I}+40 \% \mathrm{DeSO}$ & 0.57 & 0.015 & 5.58 & 1.21 \\
\hline $\mathrm{I}+40 \% \mathrm{CD}$ & 0.67 & 0.012 & 8.41 & 1.88 \\
\hline
\end{tabular}

In an alkaline environment, the relative leachability of $\mathrm{Ca}^{2+}, \mathrm{Mg}^{2+}$ and $\mathrm{SO}_{4}{ }^{2-} \mathrm{de}-$ creased for all the studied additives. The leaching of $\mathrm{Mg}^{2+}$ was especially poor, being on the level of $0.005 \%$ and $0.072 \%$ for all samples (Table 4 ). The decrease in the leachability of $\mathrm{SO}_{4}{ }^{2-}$ was remarkable, falling from $96.4 \%$ and $56.2 \%$ in the Arumetsa and illitic clay, respectively, to the level of $0.57-4.32 \%$. This was caused first by the low content of sulfur in the original clays $\left(0.08 \%\right.$ in both, expressed as $\mathrm{SO}_{3}$ (Table 2$\left.)\right)$, being quite soluble in alkali, and second by the high content of it in the additives - anhydrite and arcanite-which transformed mostly or completely into an amorphous phase (Table 3), being of poor solubility in an alkaline environment (Table 4). 
The leachability of $\mathrm{K}^{+}$, especially in the case of the clinker dust additive, increased two (from $4.48 \%$ up to $8.05 \%$ ) and four (from $2.16 \%$ up to $8.41 \%$ ) times in the blends based on Arumetsa and illitic clay, respectively (Table 4). This was caused by the highest content of potassium-containing minerals-leucite and sanidin-being in these blends.

Therefore, the OS ash and clinker dust additives increased the solubility of the thermally treated samples in the acidic environment and decreased it (except for the potassium) in the alkaline environment.

\subsection{Kinetic Calculations}

The differential isoconversional Friedman method was applied for calculation of the kinetic parameters from the data obtained under non-isothermal conditions. The equation describing the isoconversional approach, derived from the Friedman differential method, can be expressed by the following equation:

$$
\ln (d \alpha / d t)=\ln [A(\alpha) f(\alpha)]-E(\alpha) / R T
$$

where $\alpha$ is the degree of conversion, $A$ is the pre-exponential factor, characterising the frequency of the effective collisions, $E$ is the activation energy in $\mathrm{kJ} / \mathrm{mol}, R$ is the gas constant expressed as $\mathrm{R}=8314 \times 10^{-3} \mathrm{~kJ} / \mathrm{mol} \times \mathrm{K}$ and $T$ is the temperature $(\mathrm{K})$.

The function dependent on the reaction model $f(\alpha)$ becomes a constant at each fixed conversion degree $\alpha$, and the relationship between the logarithm of the reaction rate $d \alpha / d t$ and $1 / T$ is linear with a slope of $E(\alpha) / R$.

The values of the activation energy $E$, calculated in the range of a conversion level $0.1<\alpha<0.9$ for the Arumetsa and illitic clay, and for the blends with OS ash or clinker dust additives are presented in Figures 9 and 10 and in Table 5.

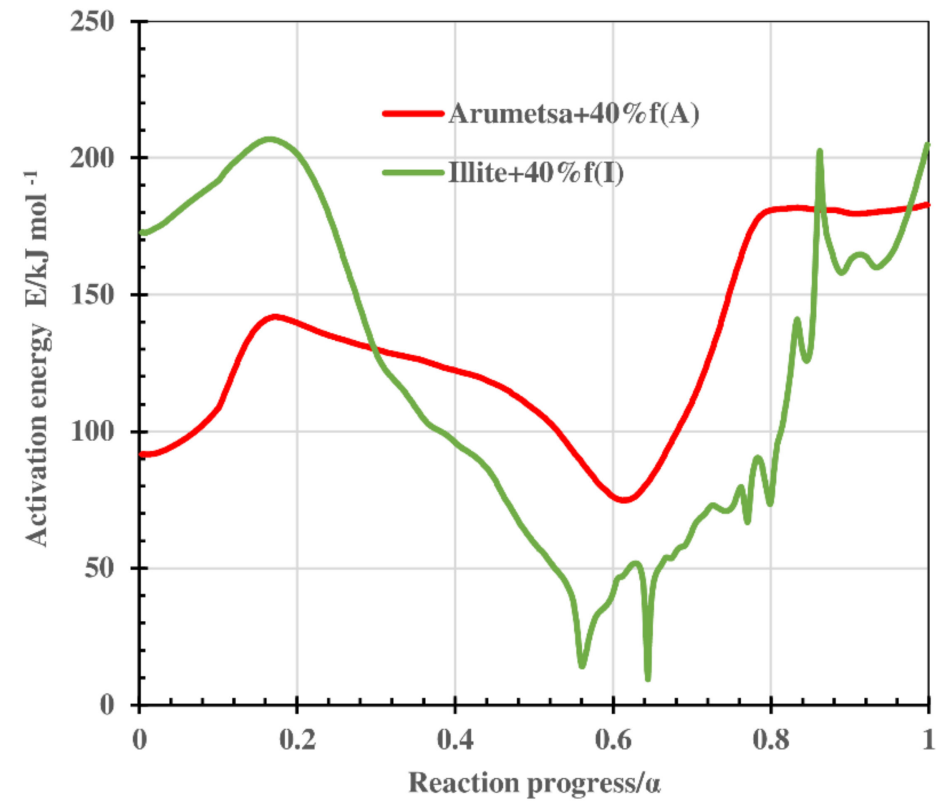

Figure 9. Value of the activation energy $E$ determined by Friedman analysis as a function of the conversion degree $\alpha$ for thermooxidative decomposition of Arumetsa and illitic clay with $40 \%$ grog.

For example, the value of the activation energy $E$ for the Arumetsa as well as illitic clay with $40 \%$ grog followed similar pattern, varying for the illitic clay over a larger range (between 9 and $206 \mathrm{~kJ} \mathrm{~mol}^{-1}$ instead of 75 and $182 \mathrm{~kJ} \mathrm{~mol}^{-1}$ for the Arumetsa clay) (Figure 9), characterizing the different overlapping processes taking place in the thermal treatment of the clay samples: emission of physically bound water, thermooxidation of organic matter, dehydroxylation of different clay minerals and, at highest temperatures, 
different reactions with the formation of secondary silicates. In addition, for the Arumetsa clay, decomposition of the carbonates took place.
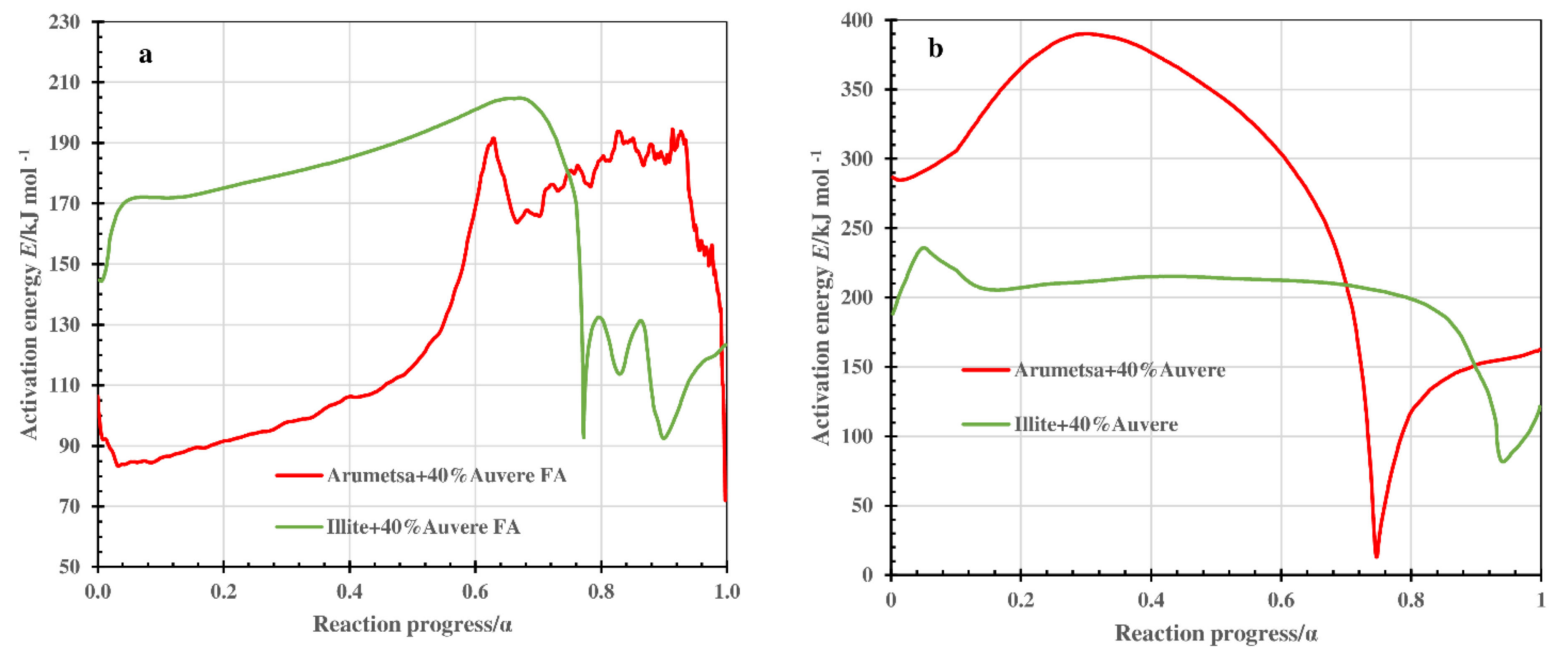

Figure 10. Value of activation energy $E$ determined by Friedman analysis as a function of the conversion degree $\alpha$ for thermooxidative decomposition of Arumetsa and illitic clay with $40 \%$ Auvere FA in step I (a) and step II (b).

Table 5. The activation energy $E / \mathrm{kJ} \mathrm{mol}^{-1}$ vs. reaction progress $\alpha(\alpha$ between 0.1 and 0.9 ).

\begin{tabular}{|c|c|c|}
\hline \multirow{3}{*}{ Sample } & \multicolumn{2}{|c|}{$E / \mathrm{kJ} \mathrm{mol}^{-1}$} \\
\hline & Step I & Step II \\
\hline & Variation/Average & Variation/Average \\
\hline Arumetsa clay(A) + 40\%fired(f)(A) & $75-182 / 128$ & - \\
\hline$A+20 \% f(A)+20 \%$ Auvere FA, H & $164-193 / 202$ & $194-210 / 205$ \\
\hline$A+20 \% f(A)+20 \%$ DeSOx, H & $119-169 / 138$ & 190-201/197 \\
\hline$A+20 \% f(A)+20 \% C D, H$ & $14-114 / 73$ & $201-213 / 207$ \\
\hline $\mathrm{A}+40 \%$ Auvere FA, $\mathrm{H}$ & $86-194 / 135$ & $15-390 / 236$ \\
\hline $\mathrm{A}+40 \% \mathrm{DeSOx}, \mathrm{H}$ & $78-158 / 119$ & $153-222 / 164$ \\
\hline $\mathrm{A}+40 \% \mathrm{CD}, \mathrm{H}$ & $77-148 / 117$ & $211-221 / 214$ \\
\hline $\mathrm{A}+20 \% \mathrm{CD}, \mathrm{H}+20 \%$ Auvere FA, $\mathrm{H}$ & $111-168 / 130$ & $158-217 / 199$ \\
\hline $\mathrm{A}+20 \% \mathrm{CD}, \mathrm{H}+20 \% \mathrm{DeSO}, \mathrm{H}$ & $75-124 / 93$ & $189-203 / 193$ \\
\hline Illitic clay $(\mathrm{I})+40 \% \mathrm{f}(\mathrm{I})$ & 9-206/113 & - \\
\hline $\mathrm{I}+20 \% \mathrm{f}(\mathrm{I})+20 \%$ Auvere FA, $\mathrm{H}$ & $144-331 / 185$ & $194-235 / 212$ \\
\hline $\mathrm{I}+20 \% \mathrm{f}(\mathrm{I})+20 \% \mathrm{CD}, \mathrm{H}$ & $18-76 / 35$ & $206-220 / 213$ \\
\hline $\mathrm{I}+40 \%$ Auvere FA, $\mathrm{H}$ & $94-201 / 170$ & $85-220 / 204$ \\
\hline $\mathrm{I}+40 \% \mathrm{CD}, \mathrm{H}$ & $11-141 / 76$ & $154-220 / 208$ \\
\hline $\mathrm{I}+20 \% \mathrm{CD}, \mathrm{H}+20 \%$ Auvere FA, H & $125-188 / 163$ & $186-223 / 207$ \\
\hline
\end{tabular}

For the clay samples with OS ash or clinker dust additives, the decomposition of the blends took place in two steps. In the low-temperature region (step I, depending on a heating rate up to $600{ }^{\circ} \mathrm{C}$ ), the emission of physically bound water, thermooxidation of organic matter and decomposition of portlandite contained in the OS ashes took place, and the dehydroxylation processes of the clay minerals started. Certain differences could be followed in the patterns of the kinetic parameters, depending on the clay used. For example, for the blend of Arumetsa clay with $40 \%$ Auvere FA, the value of the activation energy $E$ in 
the range of the conversion level $0.1<\alpha<0.5$ increased slowly from 84 to $115 \mathrm{~kJ} \mathrm{~mol}^{-1}$, with a following sharp increase reaching around $\alpha=0.62$ to the level of $193 \mathrm{~kJ} \mathrm{~mol}^{-1}$ and then varying on this level up to $\alpha=0.9$ (Figure 10a).

For the blend of illitic clay with $40 \%$ Auvere FA, the activation energy up to $\alpha=$ 0.65 also followed a permanent slow increase from 175 up to $205 \mathrm{~kJ} \mathrm{~mol}^{-1}$, but then it decreased sharply to the level of $93 \mathrm{~kJ} \mathrm{~mol}^{-1}$ at $\alpha=0.76$ and varied after that between 90 and $130 \mathrm{~kJ} \mathrm{~mol}^{-1}$ until a reaction progress of 0.9 (Figure 10a).

In the high-temperature region (step II, between $550{ }^{\circ} \mathrm{C}$ and $900{ }^{\circ} \mathrm{C}$ ), the dehydroxylation of the clay minerals continued. Decomposition of the carbonates started, and different high-temperature reactions with the formation of many new secondary silicates and alumosilicates occurred. Additionally, the formation of a liquid phase started. For this step, the activation energy $E$ in the range of a conversion level $\alpha$ from 0.1 to 0.3 for the blend of Arumetsa clay with $40 \%$ Auvere FA increased from 240 to $340 \mathrm{~kJ} \mathrm{~mol}^{-1}$, followed by a permanent decrease to $15 \mathrm{~kJ} \mathrm{~mol}^{-1}$ at $\alpha=0.74$ and, thereafter, an increase up to $100 \mathrm{~kJ} \mathrm{~mol}^{-1}$ (at $\alpha=0.9$ ) (Figure 10b).

For the blend of illitic clay with $40 \%$ Auvere FA, the activation energy pattern was quite different compared with that based on Arumetsa clay, having a reaction progress between 0.1 and 0.7 which stayed constant on the level of $210-220 \mathrm{~kJ} \mathrm{~mol}^{-1}$ and then decreased sharply to $135 \mathrm{~kJ} \mathrm{~mol}^{-1}$ at $\alpha=0.9$ (Figure 10b).

The calculated kinetic parameters $E$ and $A$ for all the blends studied are presented in Table 5. The average values of the activation energy $E$ calculated in the range of conversion level $0.1<\alpha<0.9$ were, as a rule, higher for the blends based on Arumetsa clay, which has a more complex chemical and mineralogical composition than illitic clay (Tables 1 and 2).

\section{Conclusions}

The influence of oil shale ash and clinker dust additives on the thermal behavior of clays from the Arumetsa (Estonia) and Füzzérradvány (Hungary) deposits was studied, and the following conclusions can be drawn:

- The decomposition of the blends occurred in two steps instead of one, which is characteristic of green clays. In addition to the emission of hygroscopic water, dehydroxylation of clay minerals and thermooxidation of organic matter, the decomposition of portlandite contained in the OS ashes took place at 550-600 ${ }^{\circ} \mathrm{C}$ (step I). During step II (between $550-600{ }^{\circ} \mathrm{C}$ and $1050^{\circ} \mathrm{C}$ ), the dehydroxylation processes continued, decomposition of the carbonates contained in the OS ashes and clinker dust took place, and different solid phase reactions with the formation of secondary silicates occurred.

- Therefore, Arumetsa and illitic clay follow single-step decomposition, but their blends with OS ash or clinker dust follow two-step decomposition, shifting the formation of a liquid phase to higher temperatures.

- These processes are accompanied by contraction and expansion of the ceramic bodies, with the corresponding changes in the specific surface area and porosity values leading to remarkable changes in the structures of the ceramic bodies caused by the formation of a liquid phase. The OS ash and clinker dust additives shifted the formation of a liquid phase to higher temperatures.

- The acid-alkali resistance test of thermally treated ceramic bodies on the leachability of $\mathrm{Ca}^{2+}, \mathrm{Mg}^{2+}, \mathrm{K}^{+}$and $\mathrm{SO}_{4}{ }^{2-}$ showed that in an acidic environment, the relative leachability of all cations increased remarkably. The leachability of the sulfate ions decreased in the case of OS ash additives but increased in the case of clinker dust. In an alkaline environment, the leachability of $\mathrm{Ca}^{2+}, \mathrm{Mg}^{2+}$ and especially $\mathrm{SO}_{4}{ }^{2-}$ decreased, but the leachability of $\mathrm{K}^{+}$increased, particularly in the case of the clinker dust additive containing notably more arcanite compared with the OS ashes.

- The value of the activation energy $E$ changed in the reaction progress range of $0.1<\alpha<0.9$ within the large limits for clays, as well as for blends that indicated the complex character of the processes occurring in the thermal treatment of the clays and blends. 
Author Contributions: Conceptualization: T.K., I.Š. and A.T.; formal analysis: M.U., M.E., R.T., M.V. and J.J.; methodology and interpretation: T.K., T.H., R.T. and M.V. All authors have read and agreed to the published version of the manuscript.

Funding: This study was partly supported by the Estonian Ministry of Education and Research (IUT33-19).

Data Availability Statement: These studies have no published or reported data in any open databases.

Conflicts of Interest: The authors declare no conflict of interest.

$\begin{array}{ll}\text { Abbreviations } \\ \text { CD } & \text { Clinker dust } \\ \text { CFBC } & \text { Circulating fluidized bed combustion } \\ \text { DeSOx } & \text { Semi-dry desulfurization system } \\ \text { DTA } & \text { Differential thermal analysis } \\ \text { DTG } & \text { Differential TG } \\ \text { EGA } & \text { Evolved gas analysis } \\ \text { ESPA } & \text { Electrostatic precipitator ash } \\ \text { FA } & \text { Fly ash } \\ \text { FTIR } & \text { Fourier transform infrared } \\ \text { MS } & \text { Mass spectroscopy } \\ \text { OS } & \text { Oil shale } \\ \text { PF } & \text { Pulverized firing } \\ \text { BET SSA } & \text { Brunauer-Emmett-Teller specific surface area } \\ \text { TG } & \text { Thermomechanical analysis } \\ \text { TMA } & \text { Thermomechanical analysis } \\ \text { XRD } & \text { X-ray diffraction }\end{array}$

\section{References}

1. Kaljuvee, T.; Štubňa, I.; Húlan, T.; Czáki, Š.; Uibu, M.; Jefimova, J. Influence of waste products from electricity and cement industries on the thermal behaviour of Estonian clay from Kunda deposit. J. Therm. Anal. Calorim. 2019, 138, 2635-2650. [CrossRef]

2. Eesti Energia Annual Report. 2020. Available online: http://www.energia.ee/-/doc/8644186/ettevottest/Aastaaruanne/pdf/ AA_2020_EST.pdf (accessed on 30 March 2021).

3. Heidelbrg Cement Annual Report. 2018. Available online: https://www.heidelbergcement.com/en/report-and-presentations/ annual_report_2018.pdf (accessed on 20 March 2019).

4. Brunswick Social Value Review-No 1-2020. Available online: https://www.brunswickgroup.com/media/6645/bsvr_ ellenmacarthurfoundation.pdf (accessed on 20 January 2020).

5. Realizing the Value of Circular Economy in Real Estate. Available online: https:/ /www.ellenmacarthurfoundation.org/assets/ downloads / Realising-the-value-of-circulating-economy-in-real-estate.pdf (accessed on 26 February 2020).

6. Bennhammou, A.; El Hafiane, Y.; Abourriche, A.; Abouliatim, Y.; Nibou, L.; Yaacoubi, A.; Tessier-Doyen, N.; Smith, A.; Tanouti, B. Effect of oil shale addition and sintering cycle on the microstructure and mechanical properties of porous cordierite-ceramic. Ceram. Inter. 2014, 40, 8937-8944. [CrossRef]

7. Cobîrzan, N.; Thalmaier, G.; Balog, A.-A.; Constantinescu, H.; Timiş, I.; Streza, M. Thermophysical properties of fired clay bricks with waste ceramics and paper pulp as pore-forming agent. J. Therm. Anal. Calorim. 2018, 134, 843-851. [CrossRef]

8. Furlani, E.; Tonello, G.; Maschio, S.; Aneggi, E.; Minichelli, D.; Bruckner, S.; Lucchini, E. Sintering and characterisation of ceramics containing paper sludge, glass cullet and different types of clayey materials. Ceram. Int. 2011, 37, 1293-1299. [CrossRef]

9. Sutcu, M.; Akkurt, S. The use of recycled paper processing residues in making porous brick with reduced thermal conductivity. Ceram. Int. 2009, 35, 2625-2631. [CrossRef]

10. Görhan, G.; Şimşek, O. Porous clay bricks manufactured with rice husks. Constr. Build. Mater. 2013, 40, 390-396. [CrossRef]

11. Faria, K.C.P.; Gurgel, R.F.; Holanda, J.N.F. Recycling of sugarcane bagasse ash waste in the production of clay bricks. J. Environ. Manag. 2012, 101, 7-12. [CrossRef]

12. Faria, K.C.P.; Holanda, J.N.F. Thermal behavior of ceramic wall tile pastes bearing solid wastes. J. Therm. Anal. Calorim. 2016, 123, 1119-1127. [CrossRef]

13. Pérez-Villarejo, L.; Eliche-Quesada, D.; Iglesias-Godino, F.J.; Martínez-García, C.; Corpas-Iglesias, F.A. Recycling of ash from biomass incinerator in clay matrix to produce ceramic bricks. J. Environ. Manag. 2012, 95, 5349-5354. [CrossRef]

14. Eliche-Quesada, D.; Leite-Costa, J. Use of bottom ash from olive pomace combustion in the production of eco-friendly fired clay brick. Waste Manag. 2016, 48, 323-333. [CrossRef] 
15. Fernández-Pereira, C.; de la Casa, J.A.; Gómez-Barea, A.; Arroyo, F.; Leiva, C.; Luna, Y. Application of biomass gasification fly ash for brick manufacturing. Fuel 2011, 90, 220-232. [CrossRef]

16. Coletti, C.; Maritan, L.; Cultrone, G.; Mazzoli, C. Use of industrial ceramic sludge in brick production: Effect on aesthetic quality and physical properties. Constr. Build. Mater. 2016, 124, 219-227. [CrossRef]

17. Cultrone, G.; Sebastián, E. Fly ash in clayey materials to improve the quality of solid bricks. Constr. Build. Mater. 2009, 23, 1178-1184. [CrossRef]

18. Xu, L.; Guo, W.; Wang, T.; Yang, N. Study on fired bricks with replacing clay by fly ash in high volume ratio. Constr. Build. Mater. 2005, 19, 243-247.

19. Sokolár̆, R.; Vodová, L. The effect of fluidized fly ash on the properties of dry pressed ceramic tiles based on fly ash-Clay body. Ceram. Int. 2011, 37, 2879-2885. [CrossRef]

20. Taylor, J.C. Computer programs for standardless quantitative analysis of minerals using the full powder diffraction profile. Powder Diffr. 1991, 6, 2-9. [CrossRef]

21. Ward, C.R.; Taylor, J.C.; Cohen, D.R. Quantitative mineralogy of sandstones by X-ray diffractrometry and normative analysis. J. Sed. Res. 1999, 69, 1050-1062. [CrossRef]

22. Friedman, H.L. Kinetics of thermal degradation of char-forming plastics from thermogravimetry. Application to phenolic plastic J. Polym. Sci. 1965, 6C, 183-195. [CrossRef]

23. AKTS. Softwear and Setaram Instruments: A Global Solution for Kinetic Analysis and Determination of the Thermal Stability of Materials; AKTS AG: Siders, Switzerland, 2006; p. 88.

24. Dweck, J. Qualitative and quantitative characterization of Brazilian natural and organophilic clays by thermal analysis. J. Therm. Anal. Calorim. 2008, 92, 129-135. [CrossRef]

25. Shvarzman, A.; Kovler, K.; Grader, G.S.; Shter, G.E. The effect of dehydroxylation/amorphization on pozzolanic activity of kaolinite. Cem. Conc. Res. 2003, 33, 405-416. [CrossRef]

26. Faria, K.C.P.; Holanda, J.N.F. Thermal study of clay ceramic pastes containing sugargrane bagasse ash waste. J. Therm. Anal. Calorim. 2013, 114, 27-32. [CrossRef]

27. Kaljuvee, T.; Trikkel, A.; Kuusik, R. Decarbonization of natural lime-containing materials and reactivity of calcined products towards $\mathrm{SO}_{2}$ and $\mathrm{CO}_{2}$. J. Therm. Anal. Calorim. 2001, 64, 1229-1240. [CrossRef]

28. Kaljuvee, T.; Kuusik, R.; Radin, M.; Bender, V. Carbon dioxide binding in the heterogeneous systems formed at combustion of oil shale: 4. Reactivity of ashes towards acid gases in the system fly ash-flue gases. Oil Shale 2004, 21, 13-26.

29. Štubňa, I.; Trník, A.; Vozár, L. Thermomechanical and thermodilatometric analysis of green alumina porcelain. Ceram. Int. 2009, 35, 1181-1185. [CrossRef]

30. Ptáček, P.; Frajkorová, F.; Šoukal, F.; Opravil, T. Kinetics and mechanism of three stages of thermal transformation of kaolinite to metakaolinite. Powder Technol. 2014, 264, 439-445. [CrossRef]

31. Sánches-Soto, P.J.; Ruiz-Conde, A.; Bono, R.; Raigón, M.; Garzón, E. Thermal evolution of a slate. J. Therm. Anal. Calorim. 2007, 90, 133-141. [CrossRef]

32. Knapek, M.; Húlan, T.; Minárik, P.; Dobroň, P.; Štubňa, I.; Stráská, J.; Chmelík, F. Study of mickrocraking in illite-based ceramics during firing. J. Eur. Ceram. Soc. 2016, 36, 221-226. [CrossRef]

33. Húlan, T.; Trník, A.; Medved, I. Kinetics of thermal expansion of illite-based ceramics in the dehydroxylation region during heating. J. Therm. Anal. Calorim. 2017, 127, 291-298. [CrossRef]

34. Cizer, Ö.; Rodrigues-Navarro, C.; Ruiz-Agudo, E.; Elsen, J.; Van Gemert, D.; Van Balen, K. Phase and morphology evolution of carbonate precipitated by carbonation of hydrated lime. J. Mater. Sci. 2012, 47, 6151-6165. [CrossRef]

35. Eisazadeh, A.; Kassim, K.A.; Nur, H. Solid-state NMR and FTIR studies of lime stabilized montmorillonitic and lateritic clays. Appl. Clay. Sci. 2012, 67-68, 5-10. [CrossRef]

36. Madejová, J. FTIR techniques in clay mineral studies. Vib. Spectrosc. 2003, 31, 1-10. [CrossRef]

37. Davarcioğlu, B.; Çift Yi, E. Investigation of Central Anatolian Clays by FTIR Spectroscopy (Arapli-Yesilhisar-Kayseri, Turkey). Int. J. Nat. Eng. Sci. 2009, 3, 167-174.

38. Shoval, S.; Yadin, E.; Panczer, G. Analysis of thermal phases in calcareous Iron Age pottery using FT-IR and Raman spectroscopy. J. Therm. Anal. Calorim. 2011, 104, 515-525. [CrossRef]

39. Alver, B.E.; Dikmen, G.; Alver, Ö. Investigation of the influence of heat treatment on the structural properties of illite-rich clay mineral using FT-IR, ${ }^{29}$ Si MAS NMR, TG and DTA methods. Anadolu Univ. J. Sci. Technol. A Appl. Sci. Eng. 2016, 17, 823-829.

40. Mozgawa, W.; Król, M.; Dyczek, J.; Deja, J. Investigation of the coal fly ashes using IR spectroscopy. Spectrochim. Acta Part A 2000, 56, 1819-1823. [CrossRef] [PubMed]

41. Frost, R.L.; Vassallo, A.M. The dehydroxylation of the kaolinite clay minerals using infrared emission spectroscopy. Clays Clay Miner. 1996, 44, 635-651. [CrossRef]

42. Diko, M.; Ekosse, G.; Ogola, J. Fourier Transform Infrared Spectroscopy and thermal analysis of kaolinite clays from South Africa and Cameroon. Acta Geodyn. Geomater. 2016, 13, 149-158.

43. Zhirong, L.; Uddin, M.A.; Zhanxue, S. FT-IR and XRD analysis of Natural Na-bentonite and Cu (II)-loaded Na-bentonite Spectrochim. Acta Part A 2011, 79, 1013-1016. [CrossRef] [PubMed] 